\title{
MPRA
}

Munich Personal RePEc Archive

\section{Crossing the Lines: The Conditional Relation between Exchange Rate Exposure and Stock Returns in Emerging and Developed Markets}

Bartram, Söhnke M. and Bodnar, Gordon M.

Lancaster University Management School, Johns Hopkins University - SAIS

22 June 2006

Online at https://mpra.ub.uni-muenchen.de/14018/

MPRA Paper No. 14018, posted 12 Mar 2009 02:47 UTC 


\title{
Crossing the Lines: \\ The Conditional Relation between Exchange Rate Exposure and Stock Returns in Emerging and Developed Markets
}

\author{
Söhnke M. Bartram ${ }^{*}$ and Gordon M. Bodnar ${ }^{* *}$
}

\begin{abstract}
This paper examines the importance of exchange rate risk in the return generating process for a large sample of non-financial firms from 37 countries. We argue that the effect of exchange rate exposure on stock returns should be conditional and show evidence of a significant return premium to firmlevel currency exposures when conditioning on the exchange rate change. The return premium is directly related to the size and sign of the subsequent exchange rate change, suggesting fluctuations in exchange rates themselves as a source of time-variation in currency risk premia. For the entire sample the return premium ranges from 1.2 - 3.3\% per unit of currency exposure. The premium is larger for firms in emerging markets, while in developed markets it is statistically significant only for local currency depreciations. Overall, the results indicate that exchange rate exposure plays an important role in generating cross-sectional return variation. Moreover, we show that the impact of exchange rate risk on stock returns is predominantly a cash flow effect as opposed to a discount rate effect.
\end{abstract}

Keywords: Exchange rate exposure, exchange rate risk, return premia, international finance

JEL Classification: G3, F4, F3

First version: June 22, 2006

This version: March 6, 2009

* Lancaster University, Management School, Lancaster LA1 4YX, United Kingdom, phone: +44 (1524) 592 083, fax: +1(425)952 10 70, email: <s.m.bartram@lancaster.ac.uk>, internet: <http://www.lancs.ac.uk/staff/bartras1/>.

** Johns Hopkins University, SAIS, 1717 Massachusetts Ave NW Ste 704, Washington, DC 20036, USA, phone: +1 (202) 663 7731, fax: +1 (202) 663 7718, Email: <bodnar@jhu.edu>, Internet: <http://www.saisjhu.edu/faculty/bodnar/>.

Helpful comments and suggestions by Greg Brown, Jay Choi, Pasquale Della Corte, Jean Helwege, John Hund, Michael Melvin, Greg Pawlina, Duncan Shand and Jiang Wang as well as seminar participants at the Bank of England, Essex University, Exeter University, Johns Hopkins University, the University of North Carolina at Chapel Hill, SSgA, Strathclyde University, the Adam Smith Asset Pricing Conference 2008 at London Business School and the Emerging Markets Conference 2008 at Cass Business School are greatly appreciated. The first author gratefully acknowledges the warm hospitality of the Department of Finance, Kenan-Flagler Business School of the University of North Carolina, the Department of Finance, Red McCombs School of Business, University of Texas at Austin, and the Financial Markets Group at the London School of Economics during visits to these institutions. Paulo Alves and Florian Bardong provided excellent research assistance. 


\title{
Crossing the Lines: \\ The Conditional Relation between Exchange Rate Exposure and Stock Returns in Emerging and Developed Markets
}

\begin{abstract}
This paper examines the importance of exchange rate risk in the return generating process for a large sample of non-financial firms from 37 countries. We argue that the effect of exchange rate exposure on stock returns should be conditional and show evidence of a significant return premium to firmlevel currency exposures when conditioning on the exchange rate change. The return premium is directly related to the size and sign of the subsequent exchange rate change, suggesting fluctuations in exchange rates themselves as a source of time-variation in currency risk premia. For the entire sample the return premium ranges from 1.2 - 3.3\% per unit of currency exposure. The premium is larger for firms in emerging markets, while in developed markets it is statistically significant only for local currency depreciations. Overall, the results indicate that exchange rate exposure plays an important role in generating cross-sectional return variation. Moreover, we show that the impact of exchange rate risk on stock returns is predominantly a cash flow effect as opposed to a discount rate effect.
\end{abstract}


"The key but far from straightforward question is of course "bow mucb" exchange rate movements matter."

Exchange rate moves in a global economy: a central banking perspective, Speech by Gertrude Tumpel-Gugerell, Member of the Executive Board of the ECB, at the Federal Reserve

Bank of Philadelphia, Philadelphia, 3 December 2004

\section{Introduction}

A fundamental issue in modern global finance is the degree to which exchange rate fluctuations influence firms' stock returns. Of course changes in exchange rates can affect stock returns either by altering firms' expected cash flows or the cost of capital used to discount these cash flows. Previous work has been done on both of these dimensions. One branch of research has looked at the pricing of exchange rate risk in formal asset pricing models, but the results are mixed (e.g., Roache and Merritt, 2006; Vassalou, 2000; Prasad and Rajan, 1995; Gupta and Finnerty, 1992; Jorion, 1991). Doukas, Hall and Lang (1999), De Santis and Gérard (1998) and Dumas and Solnik (1995), among others, provide support for the existence of a time-varying risk premium for exchange rate risk using conditional pricing models, but offer little insight into the expected size of the premium or the source of its time variation. More recently Francis et al. (2007) show evidence of a time-varying currency premium for U.S. industries that they estimate adds about $2.47 \%$ to the cost of equity and accounts for approximately $11.7 \%$ of the total risk premium in absolute value. However, they are unable to trace the premium down to the level of the firm. Another branch of research on this broad question looks at the sensitivity between exchange rate changes as stock return and focuses on estimating exposures (e.g., Dominguez and Tesar, 2006, 2001a,b; Allayannis and Ihrig, 2001; Williamson, 2001; He and Ng, 1998; Bodnar and Gentry, 1993; Jorion, 1990). These studies demonstrate that the past distribution of firm returns is to some degree related to exchange rate changes; however, they tend to focus on identifying corporate variables that explain the cross sectional variation in exposures. What is less commonly examined in this line of research is the relation between the firm-level exposures and subsequent stock return performance.

This paper investigates the importance of exchange rate exposure in the firm-level stock return generating process using a large sample of non-financial firms from 37 countries, both developed and emerging, over the period 1994 - 2006. We argue for the existence of and document a conditional relation between stock returns and their sensitivity to exchange rates where the variation is directly related to the realization of the exchange rate factor. Our results demonstrate that the product of the firm's historic exposure and the subsequent exchange rate change play a significant 
role in explaining the distribution of returns across firms in these countries. The economic magnitude of this conditional return premium per unit of exposure is significant, averaging $+3.3 \%$ (annual) for local currency depreciations and $-1.2 \%$ (annual) for local currency appreciations across all firms in all countries. The magnitude is larger for firms in the emerging markets and persists even after excluding the effects of financial crises that some of these countries experienced. For firms in developed markets, a significant return premium exists only for local currency depreciations.

Our analysis involves running rolling regressions to estimate exposures to local currency depreciations for individual firms over the previous 60 months. ${ }^{1}$ We relate these exposure estimates (along with the firms' exposures to the local market portfolio) to the firms' realized return in the subsequent month via a cross-sectional regression to obtain an average return premium per unit of exchange rate exposure for that month. Following Fama-MacBeth (1973), this process is repeated each month for the remainder of the sample period. We argue that to examine the role of exchange rate exposure in the stock return generating process, the relation between subsequent returns and exchange rate exposures must be looked at conditionally based upon how the exchange rate variable changes. Theoretically, the relation between a firm's exposure to local currency depreciation and its future stock return should be positive when the local currency depreciates, but negative when the local currency appreciates. Since local currency appreciations and depreciations occur with close to equal probability over the sample period, it is not surprising that the average effect of the exchange rate on returns at the firm level is close to zero. This proposed conditional response suggests a set of oppositely sloped relations between firm returns and exchange rate exposures, one for local currency appreciations and one for local currency depreciations. We document the existence of such a pattern of a conditional relation between exchange rate exposure and realized returns in our data.

Further, we verify that exchange rate exposure is driving this conditional return pattern by modeling return premia as being directly proportional to the realized change in the exchange rate in each country. At the same time, we consider the firms' market portfolio return premia as a function of their market betas to insure that market risk is not driving the results in some way. The results indicate that the return premia on both the exchange rate and market portfolio factors are significant

1 The exchange rate exposure we estimate is the exposure to a unit of local currency depreciation. Consequently, firms with positive exposure are positively affected by local currency depreciation, whereas firms with negative exposure are negatively affected by local currency depreciations. Thus, the return premium we are measuring is the return for exposure to local currency depreciation risk. It follows logically that positive exposure firm will benefit from positive realizations of this risk while negative exposure firms will suffer. 
functions of the factor loadings and the realization of the risk factors. The fact that the factor loadings change only slowly over time suggests the time variation in the factor returns themselves as a driver of the time-variation in the return premia of these factors.

To measure the economic magnitude of this exchange rate return premium, we examine returns to portfolios sorted on the basis of the estimated exchange rate exposures. We document a significant monotonic relation between the returns of these portfolios conditional on the change in the exchange rate. Similar to the approach used in Doidge et al. (2006) we form zero-investment portfolios on the basis of going long the extreme positive exposure quintile and short the extreme negative exposure quintile and find that the returns to these portfolios are significantly positive when the local currency depreciates and negative when the local currency appreciates. Normalizing these portfolios' returns by their net exchange rate exposure provides a crude estimate of the return premium per unit of exposure to the average local currency depreciation or appreciation. This unit return premium is $3.3 \%$ (annual) for local currency depreciations and $-1.2 \%$ (annual) for local currency appreciations.

Differences in the level of financial market depth and breadth as well as more extreme characteristics of exchange rates variables suggest that there may be differences in these return premia between firms in emerging market countries and developed market countries. As a result, we reestimate our tests separately for firms in developed markets and firms in emerging markets. As expected, there is a notable difference in results between these two samples. The conditional relation between returns and exchange rate exposure for firms in the emerging markets is larger and more significant than for firms in developed market. For the latter group the relation is only statistically significant for local currency depreciations. In both samples, the exchange rate return premia is significantly related to the exposure interacted with the realized exchange rate change. Looking at the exposure sorted portfolios, the conditional return premia on the exchange rate for the emerging market firms are much larger than the premia estimated for the full sample, at $+8.0 \%$ (annual) per unit of exposure for local currency depreciations and -5.5\% (annual) for local currency appreciations. For the developed market firms, the exchange rate premia are smaller in magnitude and only significant for local currency depreciations, at 2.3\% (annual) per unit of exposure.

These results document that across a large sample of countries, firms' experience a significant return premium for possessing exchange rate exposure. However, the impact on return is not unconditional but is directly proportional to the firm's exchange rate exposure and the realized 
change in the exchange rate over the period. Thus while exchange rate exposure has an unconditional return premium of zero, this result is really an average of significant and predictable return impacts arising directly from exchange rate exposure and the stochastic behavior of exchange rate changes over time. One question is whether this conditional return premium is a conditional risk premium (a conditional change in the required rate of return) or just a conditional shock to realized returns through the impact of exchange rate changes on the firm's current and expected future cash flows. We show - analytically and with simulations - that the cash flow channel would predict a time-varying relation between exposure and return that is directly related to the subsequent realization of the exchange rate, which is consistent with the empirical results above. In contrast, an exchange rate effect on firm value through the discount rate would lead to a relation between exchange rate movements and required returns opposite to what we observe. As a result, we conclude that the effect of exchange rate changes on stock returns must predominantly, if not exclusively, be an effect on the cash flows of a firm.

The remainder of the paper is organized as follows. Section 2 reviews the relevant literature. Section 3 describes the hypotheses, methodology, data sources and sample. In Section 4, we present the results of the empirical investigation. Section 5 discusses the issue of currency risk in international financial markets more generally, while Section 6 concludes.

\section{Related Work}

The majority of studies on the impact of exchange rates on firm performance assess the exposure of non-financial firms, typically by regressing exchange rate changes on contemporaneous stock returns in the presence of control variables. The results of this line of research typically provide only weak evidence of statistically significant currency exposures. For example, the seminal work by Jorion (1990) finds a significant impact of foreign exchange rate risk on stock prices only for $5.2 \%$ of the analyzed 287 U.S. multinationals at the 5\% level. Choi and Prasad (1995) find that only 14.9\% of the individual firms in the United States show a significant foreign exchange rate exposure at the $10 \%$ level. $^{2}$ Similar findings often occur when looking at non-U.S firms (see, e.g., He and $\mathrm{Ng}, 1998$; Prasad and Rajan, 1995).

\footnotetext{
2 Generally, these papers document a percentage of firms with significant exposures that is seldom more than twice the level of statistical significance; though subsequent work has improved upon this by changing the return horizon (Chow Lee and Solt, 1997; Bodnar and Wong, 2003).
} 
Beyond estimating exposures for individual firms most of the papers in this literature turn their attention to examining either the absolute magnitude or cross-sectional variation of the exposure estimates. These results generally confirm that firm characteristics predicted by theory as well as firm size seem to have explanatory power for the exposures (see Bartram and Bodnar (2007) for a review). ${ }^{3}$ Seldom does this strand of the literature consider the future return implications of the exposure estimates.

Another line of research in this area investigates whether exchange rate variability affects firms in terms of volatility or exposure to volatility. Eun and Resnick (1988) show that currency risk of firm returns can be diversified across international equity markets, but only to some extent. Therefore, the impact of exchange rate risk may constitute in part diversifiable risk and in part systematic risk to the firm. ${ }^{4}$ If exchange rate risk is a source of systematic risk, it should affect the firm's exposures to market risk. Bartov, Bodnar and Kaul (1996) suggest that the increase of exchange rate volatility associated with the onset of floating exchange rates after the breakdown of Bretton Woods led to an increase in both total return volatility and market betas and of multinational firms relative to comparable domestic firms. Bartram and Karolyi (2006) find that the introduction of the euro was accompanied by significant reductions in market risk exposures for nonfinancial firms in and outside of Europe. Nevertheless, neither of these papers directly measure the return premium resulting from the impact of exchange rate risk on measures of systematic risk.

While these studies demonstrate that the past distribution of firm returns is to some degree related to exchange rate changes, they tend to focus on identifying corporate variables that explain the cross sectional variation in exposures. What is less commonly examined with respect to the exchange rate exposure estimates in these studies is the relation between the exposures and subsequent stock returns. One goal of such an investigation would be to attempt determining the return premium investors receive for bearing a unit of exposure to the exchange rate factor, either unconditionally or conditionally.

3 Other studies in this line include Bodnar and Wong (2003), Allayannis and Ihrig (2001), Dominguez and Tesar (2006, 2001a, b), Griffin and Stulz (2001), and Williamson (2001).

${ }^{4}$ Regressions of international APT factors on exchange rates show a strong statistical relationship between GBP/USD, JPY/USD and FRF/USD exchange rates and international pricing factors which explain between $30 \%$ and $53 \%$ of the exchange rate changes, corroborating the hypothesis of partially diversifiable exchange rate risk (Korajczyk and Viallet, 1989). 
Of course the impact of the exchange rate on firms' required rates of return can be examined by estimating risk premium relative to an exposure over a sample period, where the currency movements are distributed something close to the unconditional distribution. ${ }^{5}$ A series of papers have used standard asset pricing models to determine whether exposure to exchange rate risk has an identifiable risk premium. The results of most of these studies, however, do not present clear evidence for the existence of an unconditional premium for exchange rate exposure. While some studies identify a significant unconditional return premium for currency exposure in the United States (Aretz et al. 2005; Kolari, Moorman and Sorescu, 2005; Dukas, Fatemi and Tavakkol, 1996; Choi, Elyasiani, and Kopecky, 1992; Dominguez, 1987) or Japan (He and Ng, 1998), other studies find no such evidence for the United States (Jorion, 1991), Japan (Brown and Otsuki, 1990; Hamao, 1988) and Australia (Loudon, 1993). A study of industry portfolios in the United States, Germany, Japan, and the U.K. yields a significant return premium for exchange rate exposure only in the first country when using 2- and 3-factor models (Prasad and Rajan, 1995). Similarly, a study that also includes the Canadian stock market finds only low significance of a return premium for the bearing of exchange rate exposure (Gupta and Finnerty, 1992).

The weak empirical evidence of an unconditional return premium for exchange rate exposure is potentially the result of time variation in the risk premium, and several empirical studies give some support for this effect. Doukas, Hall and Lang (1999) present evidence for a statistically significant time-varying currency exposure premium in Japan, though this is related to trends in the value of the yen in the two periods they study. Similarly, Francis, Hassan and Hunter (2007) present evidence of a time-varying currency exposure premium in the United States at the industry level. Other studies based on conditional pricing models that allow for time variation in return premia support the presence of a time-varying return premium for exchange rate exposure (e.g., Roache and Merritt, 2006; De Santis and Gerard, 1997,1998; Dumas and Solnik, 1995). These studies, however, do not identify the economic determinants of the time-variation of the exchange rate premium, nor do they provide investors with estimates of the required return premium per unit of exchange rate exposure.

\footnotetext{
${ }^{5}$ One potential issue with estimating currency risk premia is using a sample period in which the exchange rate trended in one direction for a majority of the time. In such a situation, it is likely that positive exposure firms outperform negative exposure firms (or vice versa) for purely cash flow exposure reasons rather than any systematic impact of the exchange rate change on the required rate of return.
} 
In contrast to time-variation in a currency exposure premium, recent research has looked at the economic significance of exposure by examining the average returns of portfolios sorted by exchange rate exposure and or its determinants. Using a large sample of firms in mostly developed markets, Doidge et al. (2006) provide evidence that firms with high international sales have higher returns than those with no international sales during periods of large currency depreciations by $0.72 \%$ per month, whereas they underperform by $1.10 \%$ per month during periods of large currency appreciations. A similar, though less pronounced return difference exists when looking at low minus high exposure to local currency depreciations portfolios, but only for large local currency depreciations.

In summary, to date the evidence that estimates of exchange rate exposure relate in a systematic way to subsequent stock returns is mixed. While many studies suggests the presence of a time varying return premium to currency exposure, there is little examination of the possible determinants of this relation. Moreover, there has been no research considering whether the relation between exchange rate exposure and firm-level stock returns is similar across developed and emerging market firms. In the section below, we discuss our methodology to examine this question directly.

\section{Methodology and Data}

To examine the importance of exchange rate exposure for firm-level stock returns, we must estimate the sensitivity of each firm's return to the change in an exchange rate factor. While the literature has debated various specifications to best estimate exposure and demonstrated that estimating these sensitivities is difficult and fraught with problems, we follow the traditional approach and estimate an exposure regression using the simple structure proposed by Adler and Dumas (1984). Thus, as in Jorion (1990), the following regression model is used:

$$
\mathrm{R}_{j t}=\alpha_{j}+\beta_{j} \mathrm{R}_{M t}+\delta_{j} \mathrm{R}_{X \mathrm{R} t}+\varepsilon_{j t}
$$

where $R_{j t}$ is the stock return of firm $j, R_{M t}$ is the return of the local market portfolio, and $R_{X R t}$ is the local currency return on a foreign currency exchange rate (index) variable. Given that the exchange rate is measured as units of local currency per an index of foreign currencies, the estimated coefficient $\delta j$ measures the exposure of firm $j$ to a depreciation of the local currency. ${ }^{6}$ Thus, firms that are

\footnotetext{
${ }^{6}$ Note, that the estimated coefficients are really exposure elasticities that measure the sensitivity of changes in firm value with regards to changes in the exchange rate, while exposure per definitionem is the amount at risk, i.e. the for-
} 
net long foreign currency (exporters, multinationals) are expected to have positive exposures, while firms that are net short foreign currency (importers) are expected to have negative exposure. Note that these are residual exposures in that they measure the sensitivity of the firm's stock return to a local currency depreciation relative to the sensitivity of the local market portfolio to a local currency depreciation. $^{7}$ Equation (1) is estimated on a firm by firm basis for rolling 60 month windows. We correct standard errors for autocorrelation and heteroskedasticity with the Newey-West procedure.

Subsequently, our estimated market betas and exchange rate exposures each period are used in a second-stage, one period cross-sectional regression to estimate the return premium associated with each risk exposure following the classic approach of Fama-MacBeth (1973):

$$
\mathrm{R}_{j}=a+b \hat{\beta}_{j}+d \hat{\delta}_{j}+e_{j}
$$

where $\hat{\beta}_{j}$ is the market beta (market exposure) of firm $j$, and $\hat{\delta}_{j}$ is the exchange rate exposure of firm $j . R_{j}$ is the stock return in the month following the estimation period of the market beta and exchange rate exposure elasticity. The estimated coefficients $b$ and $d$ are the return premia (in $\%$ per month) for a unit of exposure to each factor. We repeat the estimation of Eq. (2) for each period using updated exposure estimates from the five year rolling regression of Eq (1). Time series averages of the coefficients $b$ and $d$ are reported as the estimates of the (monthly) return premia. We correct the standard errors with the Newey-West (1987) procedure.

Return data in monthly frequency in local currency for non-financial firms during the period July 1994 to December 2006 are from DataStream. The sample covers non-financial firms from 37 countries: Argentina, Australia, Austria, Belgium, Brazil, Canada, Chile, Denmark, Finland, France, Germany, Greece, Hong Kong, India, Indonesia, Ireland, Italy, Japan, Korea, Malaysia, Mexico, the Netherlands, New Zealand, Norway, Peru, the Philippines, Portugal, Singapore, South Africa, Spain, Sweden, Switzerland, Thailand, Turkey, the United Kingdom, the United States and Venezuela. The respective value-weighted domestic market indices as well as trade-weighted foreign exchange rate indices (in local currency relative to the basket of foreign currencies (HC/FC)) are also from Data-

eign currency amount the home currency value of which changes with changes in the exchange rate. In line with most parts of the literature we will use the term exposure in this paper to refer to exposure elasticities.

7 As such, the weighted average exposure across all firms in the market (using the market portfolio weighting structure) must be zero. 
Stream. ${ }^{8}$ The top and bottom $0.1 \%$ of observations are winzorized to remove the effect of outliers. Firms are required to have at least 60 non-missing return observations and must not be classified as belonging to the financial sector (banks, unit trusts, investment companies, capital investment trusts, venture capital trusts, mutual funds, offshore investment companies, other investment, specialty and other finance companies, life and other insurance companies, etc.), resulting in a final sample of 4,404 firms representing $80 \%$ of the market capitalization of non-financial firms in each of the 37 countries. Table 1 provides descriptive summary statistics of all variables. Over the entire sample period, stocks yield an average annualized return of $10.3 \%$. The market indices have an equal weighted average annualized return of $9.6 \%$ (with a lower standard deviation), while equally weighted average exchange rate returns are relatively small $(1.0 \%$ annual).

\section{Empirical Results}

\subsection{Foreign Exchange Rate Exposure}

Table 2 reports summary statistics across all firms and time periods for the coefficient estimates, in particular the exchange rate exposure and the market beta, from the time-series estimations (Eq. (1)) estimated over rolling windows of 60 months. The first row of Panel A shows the foreign exchange rate exposure estimates. As expected, the mean exposure is close to zero, since the estimation framework is producing exchange rate exposure elasticity estimates that are measured relative to the market portfolio's exchange rate exposure elasticity. While not a mechanical result, because the market portfolios are value rather than equal weighted, the distribution is relatively symmetric, as indicated by the mean of the positive and negative coefficients, both in total and for those that are statistically significant. Following Bartram, Burns and Helwege (2006), we also test the hypothesis that the mean exposure is equal to zero. Interestingly, this hypothesis can be dismissed with high certainty, providing evidence that foreign exchange exposure is evident in stock returns in aggregate. Consistent with most of the previous research on exposure, we also find a relatively low percentage of significant exchange rate exposures. In particular, the fraction of firms with significant exposure coefficients is $6.4 \%$ for positive and $5.0 \%$ for negative exposures, which is only about double the significance level (5\% in our case) and not uncommon when compared with existing results in the literature.

${ }^{8}$ We also perform all tests using a value-weighed world market index (in local currency) instead of the local market index. Results for these specifications are qualitatively similar for the main findings in the paper. 
The relatively small percentage of firms with statistically significant exposures has generally been accepted to be largely the result of an underestimation by researchers of the endogeneity of hedging and the various channels that it can take.' Several papers show that corporate hedging reduces the sensitivity of stock returns to foreign exchange rate risk e.g., the use of financial hedging (Allayannis and Ofek, 2001), or operational hedging (e.g. Cater Pantzalis and Simkins, 2004; Kim, Mathur and Nam, 2004; Allayannis, Ihrig and Weston, 2001). Recent research documents that the combination of passthrough, operational hedging and financial risk management strategies is sufficient for explaining the observed levels of foreign exchange rate exposure for firms in developed markets. Since the estimated exchange rate exposure from Eq. (1) are net of the firms' hedging activities, firms with large underlying exposure that effectively manage this exposure will show low levels of exposure levels that will not be statistically significant.

This suggests that we should find lower percentages of significant exposures in markets with more access to instruments for and experience with managing exchange rate risk. Correspondingly, we should find a higher percentage of statistically significant exchange rate exposures in markets where risk management tools, opportunities and experience are more limited; in particular the emerging markets. ${ }^{10}$ Panel B of Table 2 ranks countries by the fraction of firms with significant exposures and highlights the ten countries with the highest and lowest fraction of significant foreign exchange rate exposure. ${ }^{11}$ The results reveal that the 10 countries with the lowest percentage of significant coefficients consist of nine industrial markets and only one emerging market country. In contrast, the 10 countries with the largest percentage of significant exposures are all emerging markets, and the percentage of significant exposure is over four times as high as compared to the industrialized countries in the lowest 10. This suggests that stock returns of firms in emerging markets are much more likely to have a significant sensitivity to exchange rate changes than firms in the developed markets.

\footnotetext{
${ }^{9}$ In fact, recent research suggests that the results of a large body of empirical evidence may not be unreasonable considering the fact that stock returns only reflect the exposure of firms net of corporate hedging (Bartram and Bodnar, 2007).

${ }^{10}$ Gopinath, Itskhoki and Rigobon (2006) suggest that firms in emerging market countries have to bear more foreign exchange rate risk when trading with developed marked firms due to lower exchange rate risk pass-through.

11 Consistent with Dominguez and Tesar (2001a) we generally find a greater percentage of significant exchange rate sensitivities amongst firms trading in emerging markets as compared to firms trading in developed markets. In particular, 30\% - 40\% of firms in emerging market countries such as Brazil, South Africa, Indonesia, Argentina, and Thailand are significantly exposed to local currency depreciations, whereas typically less than 10\% of firms from developed markets are significantly exposed to local currency depreciations.
} 


\subsection{Exchange Rate Return Premia}

\subsubsection{Evidence of an Unconditional Return Relation}

We use the estimated exchange rate exposures and market betas to estimate monthly cross-sectional return premia in a manner consistent with the approach of Fama-MacBeth (1973). ${ }^{12}$ Panel A of Table 3 reports the time-series average of the 90 monthly return premia and the $p$-values of associated $t$-tests for different samples of firms. For the entire sample of firms and countries, the results show no evidence of an unconditional return premium for exchange rate exposure. The average return premium is just $0.027 \%$ per month per unit of exposure to local currency depreciation and the test for the significance indicates that it is not statistically significant ( $p$-value $=0.396)$. Thus, in our sample there is no unconditional return premium for exchange rate exposure. This result suggests that an investor cannot expect, on average, to earn a return premium simply for holding firms that are positively or negatively exposed to exchange rate fluctuations.

\subsubsection{Evidence of an Conditional Return Relations}

While the lack of an unconditional relation is consistent with most asset pricing tests on exchange rates in a broad setting, we claim that the unconditional specification above is not appropriate for determining whether there is any relation between exchange rate exposure and realized returns. If past exposures are economically meaningful for returns, firms with positive exposures to local currency depreciations should produce higher returns than otherwise similar firms with negative exposures to local currency depreciations in those periods when the local currency actually depreciates. Similarly, in periods when the local currency appreciates, firms with negative exposures to local currency depreciations will experience higher returns than otherwise similar firms with positive exposures to local currency depreciations. This suggests that any relation between exchange rate exposures and realized returns needs to be conditional on the realization of the exchange rate change over the return measurement period. Therefore, we argue that the pattern between exchange rate exposure and subsequent returns should be positively sloped when the local currency depreciates

12 Given that the market betas and exchange rate exposures are estimated for firms in different countries, we cannot expect that they are drawn from the same distribution, as generally assumed for regression analysis. As a result, we use for the cross-sectional regressions market betas and exchange rate exposures that are estimated from regressions based on normalized data (similar procedures have been used e.g. in Brennan, Chordia, and Subrahmanyam, 1998; Llorente, Michaely, Saar, and Wang, 2001; Naik and Yadav, 2003; Odders-White and Ready, 2004). The main results are robust to this approach. 
and negatively sloped when the local currency appreciates. Such a conditional relation is plotted out in Figure 1.

To check whether such a conditional pattern exists in the data, we sort the sample firms each month into five portfolios on the basis of their estimated exchange rate exposure to local currency depreciation and plot the average portfolio performance conditional on the realization of the change in the local currency. The results for all firms are displayed in Panel A of Figure 2. The figure plots the adjusted returns of the quintile portfolios (i.e., returns net of alpha and beta times the market return) separately for when the local currency depreciates and appreciates. While not perfectly matching the predicted pattern in Figure 1, these portfolios do plot out a positively sloped line for local currency depreciations and a negatively sloped line for local currency appreciations.

To test more formally for this hypothesized relation, we report the conditional mean return premium from Eq. (2) based upon whether the local currency depreciated or appreciated over the month in which realized returns are measured. The results of these estimations are shown in Panel $\mathrm{B}$ of Table $3 .{ }^{13}$ Compared to the unconditional premium, the conditional mean return premia are striking. When there is a local currency depreciation over the month following the estimation of the exposure, the return premium for a unit of exposure to local currency depreciation is positive, $0.145 \%$ per month, and highly significant ( $p$-value $<0.001)$. Similarly, when there is a local currency appreciation over the month following the estimation of the exposure, the return premium to a unit of local currency depreciation exposure is negative, $-0.078 \%$ per month, and marginally significant $(p$-value $=0.078)$. This finding suggests that stock returns are systematically related to exchange rate exposure, just in a conditional sense.

\subsubsection{Conditional Return Relations and Realized Risk Factors}

To confirm that the exchange rate exposure return premia estimated above are really due to exchange rate changes and not some omitted correlated factor or interactions with the market portfolio, we consider an additional test. We examine whether these conditional return premia are related to the size and sign of the exchange rate change. To do this, we return to Eq(2) and model the return premia on the exchange rate, $d$, and the market portfolio, $b$, to be proportional to the realized

13 This approach is similar in structure to the approach of Pettengil et al. (1995) in which they looked at the conditional relation between the market beta and returns. This approach has been criticized by Cooper (2007) as being invalid as a test of a of an asset pricing model. However, we are not concerned about testing an asset pricing model. Our interest is to see whether exchange rate exposures conditionally relate to subsequent stock performance. 
value of the exchange rate index return, $R_{X R}$, and market index return, $R_{M}$, (respectively) in the next period:

$$
R_{j}=a+\left(b_{0}+b_{1} R_{M}\right) \hat{\beta}_{j}+\left(d_{0}+d_{1} R_{X R}\right) \hat{\delta}_{j}+e_{j}
$$

If the estimated exposures, $\hat{\beta}_{j}$ and $\hat{\delta}_{j}$, are unconditionally related to subsequent stock returns, we would expect to find significant estimates for $d_{0}$ and $b_{0}$. If the estimated exposures are related to subsequent returns in a manner proportional to the realized values of the risk factors (the realized returns of the exchange rate and market portfolio), we should expect to find significant (positive) estimates for $b_{1}$ and $d_{1}$. We display the results of this test in Panel $C$ of Table 3 . The coefficient on the interaction of the exchange rate exposure and the realized exchange rate change, $d_{1}$, is positive, 0.134 , and highly significant $(p$-value $<0.001)$. In contrast, the coefficient on the exchange rate exposure itself, $d_{0}$, is not significant. This suggests that the exchange rate return premium we identify above is directly related to returns as a function of the change (sign and size) of the exchange rate variable, but the exchange rate exposure itself is not (unconditionally) related to realized return. In other words, the return premium an investor earns on a firm as a result of the firm's exposure to exchange rates is not a function of the exposure itself, but the exposure and the realized change in the exchange rate.

Similarly, the coefficient on the interaction of the market beta and the realized market portfolio return, $b_{1}$, is large and positive, 0.829 , and highly significant ( $p$-value $<0.001$ ), while the coefficient on the market beta itself, $b_{0}$, is negative, but small. This result is in stark contrast to the importance of the market beta in Panels A and B of Table 3, where the market betas were not related at all to returns in an unconditional way. Here, in a manner consistent with the findings of previous work for U.S. stocks by Pettengill, Sundaram and Mathur (1995) and Lakonishok and Shapiro (1984), the market beta is found to be significantly related to return, but only conditionally as a function of the direction of the return to the market portfolio. ${ }^{14}$

Not surprisingly the size of the association between the firm return and the interaction of the market return and the firm's market beta is much larger than that for the exchange rate. The ratio of these coefficients allows us putting the currency return impact in context relative to the mar-

${ }^{14}$ As noted above, Cooper (2007) demonstrates that this need not imply that either of these exposures is an exante priced risk factor, only that they are ex-post useful for explaining stock return. 
ket return impact. These results suggest that for firms with similar sized exposures to local currency depreciation and market movements, the average impact on firm return of a change in the exchange rate index of one percent is only about one sixth $(16 \%=0.134 / 0.829)$ of the average impact on firm return of a market movement of one percent.

This test supports the claim of a real relation between stock returns and exchange rate exposure on a conditional basis, where the conditioning variable is the realization of the exchange rate index itself. Moreover, the variability in realized exchange rate changes over time results in variation of the return impact of exchange rates on these firms. Thus, it seems possible that this relation could be the source of the time varying risk premia for exchange exposure that previous researchers have identified, but been unable to explain. ${ }^{15}$

\subsubsection{Economic Magnitude of Exchange Rate Return Premia}

To confirm the implication of the regressions above and to measure the economic magnitude of these premia to investors, we return to the quintile portfolios sorted on the basis of estimated exchange rate exposures across all countries. Similar to the approach used in Doidge et al. (2006) we create a zero net investment portfolio from a long/short position in the two extreme exposure sorted portfolio. This portfolio is very long exposure to local currency depreciation and should be expected to produce positive returns when the local currencies depreciate and negative returns when the local currencies appreciate. Panel A of Table 4 shows the results for local currency depreciations. Looking at the adjusted returns row, the high-low exposure portfolio produces a statistically significant monthly return of $0.791 \%$, about $9.5 \%$ per year ( $p$-value $<0.001$ ). Given that the net exposure of this zero net investment portfolio to local currency depreciation is 2.875 units of exposure, the per unit of exposure return in this case is approximately 3.3\% (9.5\%/2.875) on an annualized basis. This suggests that identical firms with opposite unit exposures to local currency depreciation would be expected to produce return differences of $6.6 \%$ on an annual basis for the average exchange rate depreciation. Panel B shows the results for local currency appreciations. From the adjusted returns line the high-low portfolio produces a monthly return of $-0.290 \%$, about $-3.5 \%$ per year, with a marginal degree of statistical significance $(p$-value $=0.09)$. Given that the portfolio's net

15 Additional tests, not reported, consider the role of the volatility of these factors on the return premia by including the squared change in the risk factor as an additional explanatory variable. We find no consistent evidence that the squared factor terms help explain the conditional return premia. 
exposure to local currency depreciation in this case averages 3.024 units of exposure, the per unit of exposure return is approximately $-1.15 \%$ on an annualized basis for local currency appreciations.

\subsection{Return Premia in Relation to Market Development}

As discussed above, there are reasons to believe that exchange rate changes might differentially affect firms in the developed markets as compared to firms in emerging markets. To examine this issue, we separate the firms by country into an emerging market sample and a developed market sample based upon the classification by Morgan Stanley Capital International (MSCI). ${ }^{16}$ This classification reveals some noticeable distinctions. As we can see from Panels B and C of Table 1, there is a significant difference in the average exchange rate volatility between emerging market countries and developed market countries. In addition, and consistent with the literature on the effect of currency crisis in emerging markets, the average equity returns in the emerging markets are much better during local currency appreciations than depreciations. We already saw in Table 2 that exposure to local currency depreciation is more likely to be statistically significant in the lesser developed markets than it is in the developed markets. Given these facts, one might expect that firms in emerging markets would have a larger return premium for currency exposure.

We first look at the plots of the returns for the exposure sorted portfolios of these two groups of firms. These are shown in Panel B of Figure 2. For the emerging market firms, the slopes of the portfolio's adjusted returns conditional on the realized exchange rate change create a clear X pattern. For the developed market firms, the X pattern is less apparent as the slope of appreciation line is barely negative across the 5 portfolios. This suggests that we might find stronger results amongst the emerging market firms.

Table 5, Panel A, shows the mean return premium for the firms from the 14 emerging markets, first unconditionally and then conditionally with respect to the change in the value of the local currency. As with the full sample of countries, the unconditional return premium is small and not significantly different from zero. When looking at the return premia on a conditional basis, we see our basic results. The return premium conditional on a depreciation of the local currency is positive, $0.195 \%$ per month, and highly significant $(p$-value $<0.001)$. Similarly, the return premium condi-

${ }^{16}$ Among the 37 countries in our sample, MSCI classifies Argentina, Brazil, Chile, India, Indonesia, Korea, Malaysia, Mexico, Peru, Philippines, South Africa, Thailand, Turkey and Venezuela as emerging markets and Australia, Austria, Belgium, Denmark, Finland, France, Germany, Greece, Hong Kong, Ireland, Italy, Japan, Netherlands, New Zealand, Norway, Portugal, Singapore, Spain, Sweden, Switzerland, UK, and the United States as developed markets. 
tional on an appreciation of the local currency is negative, $-0.170 \%$ per month, and also highly significant $(p$-value $=0.004)$. Note that the magnitude of these estimates of the average return premia for the emerging market firms are noticeably larger than the size of the average return premium for the full sample.

The table also shows the same set of results for the firms from the 23 developed markets. Once again, the unconditional test shows no significant return premium. Conditioned on the exchange rate change, the return premia are the same sign as those of the emerging market firms, but smaller and less significant. In particular, the return premium for developed market firms conditional on a depreciation of the local currency is positive, $0.141 \%$ per month, and significant ( $p$-value $=0.001$, while the return premium conditional on an appreciation, while negative, is not significantly different from zero. This result for developed market firms is somewhat surprising. It suggests that there exists a systematic relation between firms' stock returns and exchange rate exposures only for local currency depreciations in the developing countries. While this could be the result of more active exchange rate risk management to protect against local currency appreciations, it does draw into question the economic significance of exchange rate exposure for these firms.

Panel B of Table 5 repeats the interacted regressions (Eq (3)) for each of the samples. The results for the emerging market firms are qualitatively the same as for the full sample: the return premia for both the exchange rate exposure and market beta are on average quite strongly related to returns when interacted with the realization of the risk factor. The coefficient on the interaction of the exchange rate exposure and the realized exchange rate return is 0.180 ( $p$-value $<0.001)$, while the coefficient on the interaction of the market beta and the realized market return is 0.843 ( $p$-value $<0.001)$. The ratio of these coefficients suggests that for firms with similar sized exposures to local currency depreciation and market movements, the average impact of a one percent exchange rate change on firm return is about $21 \%(0.180 / 0.843)$ of the average impact of a one percent change in the market portfolio.

The results for the developed market firms suggest a similar though less powerful story. There is a significant positive average relation between stock returns and the interaction of the exchange rate exposure and the realized exchange rate change, 0.123 ( $p$-value 0.003 ), though it noticeably smaller than the size of the relation found for the emerging market firms. The unconditional effect of exchange rate exposure on equity returns in this setting has an elasticity of 0.060 with a $p$ value of 0.123 . Market risk still plays a larger role in explaining returns with the coefficient on of the 
market beta and realized market return being 0.811 ( $p$-value $<0.001)$. Again, this finding is consistent with the results of earlier research examining the relation between market beta and return for the United States (e.g., Pettengill, Sundaram and Mathur, 1995; Lakonishok and Shapiro, 1984).

Table 6 repeats the return tests on the sorted portfolios for each subset of markets. These tests provide a crude measure of the size of the conditional return premium available to investors for each subset of countries. Panel A shows the results for the local currency depreciations. The returns to the high-low exposure portfolios for both samples are positive and highly significant. Dividing the high-low adjusted portfolio returns by the high - low portfolio exposures and annualizing, we get an annual return per unit of exposure to local currency depreciation of $8.0 \%$ for emerging market firms and 2.3\% for developed market firms. Panel B shows the results for local currency appreciations. The return to the high minus low portfolio is statistically different from zero only for the emerging market firms. The per unit of exposure return premium for local currency appreciations is $-5.5 \%$, while for the developed firms, as suggested by the plot, the return premium while a small negative value is not significant. This evidence suggests that the results found for the full sample are driven to a large (but not exclusive) extent by firms in countries outside developed markets.

It is interesting to consider potential reasons for the differences in the relation between foreign exchange rate exposure and stock returns in emerging market and developed market countries. To this end, Table 7 presents some relevant statistics. First, exchange rate exposure could matter more for firms in emerging market countries simply because foreign trade might be bigger. Nevertheless, the results on the size of exports and imports (relative to the size of the economy as measured by GDP) suggests that foreign trade is relatively less important for developing countries, and thus cannot explain the observed discrepancy in exchange rate effects. At the same time, international trade may lead to larger foreign exchange rate exposures of firms in emerging market countries because of less expertise and more limited possibilities to hedge exchange rate risk. By the same token, as shown in Table 7, financial markets in developing countries are less developed, limiting the possibilities of efficient risk sharing. This is documented in significantly smaller market capitalization of traded companies (as percentage of GDP) (median of 40.6 in emerging market countries versus 83.9 in developed countries) as well as domestic credit to the private sector (as percentage of GDP) (median of 35.0 in emerging market countries versus 106.9 in developed countries). Similarly, the availability of derivatives is much reduced in developing countries, where the turnover 
of foreign exchange rate and interest rate derivatives (\% of GDP) is 0.53 and 0.06 , respectively, compared to 2.39 and 2.30 in industrialized countries.

\subsection{Robustness Checks}

Many of the emerging market countries were subject to a major economic or currency crisis during the sample period. As these events are included in our sample data, it is interesting to consider the effect of these developments for the results. On the one hand, currency exposure may simply reflect the underlying economic problems rather than pure currency risk. On the other hand, currency crises may render currency exposure particularly important, due to the large currency movements they entail. Thus, it is not clear that crises periods should generally be discarded, since one can, in fact, argue that they are particularly interesting and relevant. Also, note that some of the emerging market countries (e.g. India, South Africa) were not part of a major crisis during the sample period.

To consider the influence of crises, we repeat the analysis for the emerging market firms excluding any observations for the following countries and years: Argentina (1999-2002), Brazil (19981999), Chile (1998-1999), Indonesia (1997-1999), Korea (1997-1999), Malaysia (1997-1999), Mexico (1994), Peru (1994), Philippines (1997-1999), Thailand (1997-1999), Turkey (2001), and Venezuela (1994-1996). ${ }^{17}$ The results, shown in Panel A of Table 8, are overall similar to those using all available observations for firms in emerging markets, the economic magnitude of the coefficients is even slightly larger.

Another aspect to consider in the context of exchange rate exposure is the impact of fixed exchange rate regimes. This is relevant not only because of the occurrence of exchange rate pegs amongst the emerging market countries over this period, but also because of the targeted exchange rate system and creation of the currency union amongst the European countries. While the multilateral exchange rates will still be volatile even with some fixed bilateral exchange rates, it may be interesting to consider the impact of fixed exchange rates for the results. To this end, we examine firms in emerging market countries during periods where their currency was not pegged (Table 8, Panel B) and firms in developed markets outside the Euro area (Table 8, Panel C).

${ }^{17}$ Note that we exclude stock return observations during months in these years (for the cross-sectional regression) as well as require that the exposures are estimated for 5 -year periods that do not contain observations of these years in order to insure that they are not affected by the crises events. The results are robust to various filters that are more or less conservative in excluding specific periods for particular countries. 
Limiting the sample to periods where the exchange of a country was floating still shows the same result of no unconditional, but statistically and economically significant conditional return premia for emerging market firms. ${ }^{18}$ Similarly, the results for developed markets excluding Euro area countries are very similar to those of all industrialized countries, i.e. there is no relation between exposure and stock returns unconditionally or for currency appreciations, while there is a (small) effect conditional on the local currency depreciating.

Lastly, the United States is the country with the largest number of firms and whose currency plays the largest average role in the individual exchange rate indices. Thus, it is possible that the developed country results are driven by the U.S. data. We therefore replicate the tests on the developed market firms excluding the U.S. firms in the sample. Results for omitting the U.S. firms from the developed market sample, displayed in Table 8 Panel D, show no material change on the results.

Studies on foreign exchange rate exposure typically focus on developed market countries in recent time periods, where inflation has been low. In contrast, our sample includes emerging markets, some of which had maybe less negligible levels of inflation during the sample period. It is not clear that inflation should have an effect on the results and would necessarily be a reason of concern for the estimation of return premia. Nevertheless, in order to assess the potential effect of inflation on our results, we use monthly data on local currency changes in the consumer price index from the International Financial Statistics of the IMF to adjust individual stock returns, market returns and exchange rates. Subsequently, we re-do all tests with these real returns. Table 9 shows that there is no evidence of an unconditional relation between real returns and real exchange rates, while there is also a strong conditional relation (which is weaker for developed market firms when the local currency appreciates). These results are very similar to those reported for nominal returns in Table 5. Overall, the adjustment of returns for inflation has very little effect on the results.

The summary statistics in Table 2 document that in this study (as in the rest of the literature) foreign exchange rate exposures are estimated imprecisely (almost 90\% of them are statistically insignificant). As a result, one might be concerned how meaningful the exposure estimates are, and what the implications of measurement error are for the cross-sectional regression. As common practice when employing the (widely used) Fama-MacBeth (1973) methodology, we estimate Equation (2) using ordinary least squares with a correction of the standard errors. Nevertheless, the results are

\footnotetext{
18 These results also remain when restricting the sample to firms in non-crisis, non-peg periods.
} 
similar for alternative estimation techniques, such as weighted least squares using the absolute value of the $t$-statistics (or the absolute value of the inverse of the standard errors) of the foreign exchange rate exposure coefficients as weights and thus placing more importance on observations where currency exposures are estimated with more precision.

Another concern pertains to potential errors in variables problems that may bias the standard errors (Shanken, 1992) and potentially lead to factors independent of asset returns to show significance (Kan and Zhou, 1999). To this end, we replace the actual exchange rates for all countries with normally distributed random variables that have the same mean and standard deviation as the actual exchange rates. The results show that, as expected, there is no significant relationship between these random exchange rate series and stock returns in any of the specifications or (sub)samples for our data set. This suggests that despite the fact that the exchange rate exposures are small and estimated with error, they are economically meaningful, and their relationship to stock returns is not just an artifact of the employed methodology. It also shows that the conditional effect we document is not generated by construction. Finally, we note that the portfolio sorts reported in Tables 4 and 6 do not suffer from any potential shortcomings of the Fama-MacBeth methodology and thus represent robustness tests to the findings in the paper as well.

\section{Is it a Foreign Exchange Risk Premium?}

It is tempting to look at these results and argue that this return premium is in fact a conditional exante risk premium for exposure to exchange rate risk. ${ }^{19}$ As an ex-ante risk premium, it would imply that the required rate of return that the market demands for holding the stock changes with the expectation of the exchange rate change. However, this interpretation is problematic for a couple of reasons. First, the conditioning variable here is the realized exchange rate change, which is the risk factor itself. Forecasting even the direction of the change in the exchange rate has proven very difficult. Second, it is unlikely that the only impact of the exchange rate change is on the firm's (conditional) required rate of return as it can also have a direct impact on the firm's cash flows.

Given that exchange rates convert foreign currency values to local currency, they have a mechanical impact on the local currency valuation of foreign currency transactions and assets, inde-

${ }^{19}$ As Cooper (2007) points out the form of the conditional test we use cannot be used as proof of an ex-ante relation between exchange rate exposure and return. However, the finding of such a relation is not inconsistent with there being an ex-ante relation. 
pendent of any cost of capital effect. When the local currency depreciates, firms that have foreign currency cash flows and assets (e.g., firms that would have positive exposures to local currency depreciations) will experience an increase in their local currency value because of the valuation impact of the exchange rate change on these cash flows and assets (unless they are hedged). Similarly, firms that have foreign currency payments and liabilities will experience a decrease in their local currency value because of the direct value impact of the exchange rate change on these flows and liabilities. This value effect occurs even if there is no change in the firm's required rate of return (i.e., the rate at which future cash flows are discounted). ${ }^{20}$

Obviously the conditional return premium we document in response to exchange rate changes could be a combination of both the cash flows channel as well as the required rate of return channel. It could be that the depreciation of the local currency both increases the cash flows to firms with a positive exposure as well as increases the required rate of return due the conditional risk premium from the local currency devaluation. Since the increased cash flow and the increased required rate of return counterbalance one another with respect to their impact on the current value of the firm, it is difficult to call the net impact on the firm's return purely a conditional premium for currency risk.

To consider this further, take the value of a firm as the present value of its stream of expected future free cash flows $(F C F)$, discounted back to today by the required rate of return given some asset pricing model based upon the non-diversifiable risks of the cash flows:

$$
P_{0}=\sum_{t=1}^{\infty} \frac{E_{0}\left(F C F_{t}\right)}{(1+E(r))^{t}}
$$

If we simplify this expression by assuming a perpetuity structure, one in which the expected free cash flows are fixed at $E(F C F)$, the expression reduces to

$$
P_{0}=\frac{E(F C F)}{E(r)}
$$

When we consider the impact of a change in the exchange rate, $S(H C / F C)$ on the price of the firm, we can see that the sensitivity of the price of the firm to the exchange rate change is a posi-

\footnotetext{
20 The same, but opposite story is true when the local currency appreciates.
} 
tive function of the sensitivity of the value of FCF to the exchange rate change and a negative function of the sensitivity of the required rate of return to the exchange rate change:

$$
\delta=\frac{\partial \ln (P)}{d \ln (S)}=\frac{\partial \ln (E(F C F))}{d \ln (S)}-\frac{\partial \ln (E(r))}{d \ln (S)}
$$

Empirically we can measure the term on the left hand side of Eq (6), this is the exchange rate exposure elasticity of the firm. This relation can be positive or negative, depending on the nature of the firm. Our empirics suggest that firms with positive (negative) exposures, based upon recent past data, tend to experience a positive (negative) change in price in the next period when the home currency depreciates during that period, while the opposite pattern occurs when the home currency appreciates during the next period.

It is apparent from Equation (6) that any change in price resulting from a change in the exchange rate must occur via either a change in cash flows or a change in the required rate of return, or some combination of the two channels. What is important to note is that one channel affects the price relation positively and the other negatively. Thus for a firm whose price rises with a depreciation of the home currency (an increase in $S$ ), it has to be the case that the exchange rate change has increased the expected stream of future cash flows or that the exchange rate change has reduced the required rate of return on the cash flows.

Consider the case of a firm with a positive exposure to the exchange rate (home currency price of foreign currency). Such a firm would see an increase in its price in response to a depreciation of the home currency. One explanation for this positive relation is purely through the cash flow channel, with no impact on the required rate of return. The exchange rate, denoted as the home price of foreign currency $(S(H C / F C))$ is the rate that is used to convert the foreign currency cash flows the firm has or expects to have in the future into home currency. A depreciation of the home currency is an increase in the exchange $(H C / F C)$, and this rate and its future expected values (which must also increase to prevent profitable speculative arbitrage - unless there was a significant shift in the risk-free yield curves between $H C$ and $F C$ ) will mechanically result in larger $H C$ values for current and future free cash flows denominated in FC. Thus the value of the firm today would rise in response to a home currency depreciation purely because the new, higher exchange rate and its higher future expectations would lead to higher free cash flow in home currency. With a fixed discount rate, this would lead to an increase in the price of the firm today. 
To verify this effect, we create a simulation for a firm with $100 \%$ FC cash flows that are assumed to be fixed in FC in perpetuity. Using the current exchange rate and its future expectations, based directly upon interest rate parity (as we are assuming no currency risk premium), we convert the FC cash flows into $H C$ and discount them at a fixed $H C$ required rate of return that is not a function of the exchange rate. Then, by generating a set of exchange rate shocks, we are able to obtain a time series of values for this firm by discounting the fixed foreign currency cash flows by the randomly changing exchange rates (and their future expectations). Taking the changes in the price of the firm and regressing them against the exchange rate changes, we confirm that such a firm has an exchange rate exposure (sensitivity) of exactly 1.0. This firm displays the features of firms with positive exchange rate exposure: Its value rises when the $H C$ depreciates, and its value declines when the $H C$ appreciates. All of this occurs just due to the cash flow channel for the exchange rate impact on the value of the firm. This is the channel for a link between exchange rate changes and firm value that has received the most attention in the literature and is commonly discussed by researchers coming at this question from the corporate finance side. Thus, the cash flow channel would predict a time-varying relation between exposure and realized return that is directly related to the subsequent realization of the exchange rate, which is consistent with the empirical results above.

An alternative explanation for a positive exchange rate price relation is that exchange rate changes have an impact on the required rate of return as opposed to the expected cash flows. To explore this possibility, we consider the extreme case of a firm with a positive exposure to exchange rate changes, whose cash flows are not affected by the exchange rate. In this case, the relation between the exchange rate change and firm value can only occur through a change in the required rate of return, (i.e., the firm's discount rate). Since the exchange rate - firm value relation does not appear to be unconditional, it must be the case that the required return component related to the exchange rate is time varying. Given the above results, we assume that the exchange rate risk premium is conditional on the change in the exchange rate. We will also assume that the current required rate of return is the rate used to discount all future cash flows. ${ }^{21}$

${ }^{21}$ It is possible that the discount rate is affected only temporarily by the current exchange rate change and that after some number of periods (perhaps one!), the rate reverts back to the unconditional rate, which is not significantly different between positively and negatively exposed firms. Such a shortening of the length of time the required rate of return was changed would require larger values for $E\left(R_{F X}-r_{F}\right)$ in order to bring about the changes in firm value from exchange rate changes of the size we document in the analysis. 
For this specification, what would the pattern of the return premium need to look like to account for the conditional relation documented above? From Equation (4) it is the case that the relation between required return and price is an inverse one. Thus, for a positively exposed firm to experience an increase in price when the home currency depreciates, we would need the required return used to discount the (unchanged) cash flows to decline. Thus the risk premium for pure foreign currency returns (in home currency) would have to be negative in order for firms with positive exposure to the exchange rate to have lower (higher) required rates of return when the home currency depreciates (appreciates). The reason for this situation is that cash flows are assumed to be fixed and the inverse relation between price and required return in Equation (5).

To investigate the required rate of return channel for the exchange rate to impact firm value, we consider the simulation of an alternative firm. This firm is assumed to have no cash flows impact from the exchange rate, so that its cash flows are fixed in $H C$ in perpetuity. The only way the exchange rate changes influence the value of this firm is through the required rate of return used to discount the cash flows. If this firm were to have an exchange rate exposure of the same size as the other firm, 1.0, what would the size of the expected risk premium, conditional on the sign of the change in the exchange rate, have to be to produce changes in value that are consistent with an exposure of 1.0? The results suggest a very small risk premium per unit of exchange rate exposure, $-0.25 \%$ (annual), in order to generate future returns that produce the assumed exposure of 1.0. Of course if we assumed that the persistence of the impact of the exchange rate on the required rate of return were not infinite, this premium would become much larger. Nonetheless, such a risk premium would be able to consistently explain the empirical relation between positively exposed firms and exchange rate changes documented earlier under the assumption that the exchange rate is not affecting the value of the firm's cash flows.

The implication of the required rate of return channel is that the realized return will not match the required return. In the period that the home currency depreciates, the positively exposed firm's value rises (empirical fact), but the required rate of return channel implies that the required rate of return must fall. The predicted return would match the realized return in future periods if the exchange rate were to stay constant as the increased price today implies lower average returns in the future, but in the current period these returns diverge. More significantly, in a world in which the exchange rate is changing randomly, the observed return and the required return would consistently deviate. 
It is also possible that both the cash flow channel and the required rate of return channel are at work at the same time. Since the cash flow effect provides the pattern of the return behavior we observe, allowing both channels to influence returns simultaneously would allow for the possibility of a positive required return to the return factor. However, it would still have to be the case that the cash flow impact dominated the required return impact to keep the effect consistent with the empirical results.

The implication of this result is two-fold. It is possible that the observed relation between the exchange rate and firm value is driven purely by a cash flow effect and that there is no impact on the required rate of return. Observed returns would fluctuate for cash flow valuation reasons, but since this effect is random and impacts $H C$ returns on firms with different exposures in opposite ways, it is treated by the market as a diversifiable risk. Alternatively, there could be a channel in which the required rate of return varies in a systematic fashion with the realized pattern of the exchange rate. In such a case, for the rate of return channel to be the primary manner in which the value of the firm changes, the premium on the foreign currency risk would be negative and relatively small $(-0.25 \%$ annual, as compared to a market portfolio return premium of $4 \%-6 \%)$.

\section{Conclusion}

While a large body of research has focused on estimating exchange rate exposures, with attention to either the percentage that are statistically significant and/or attempting to explain their cross sectional variation, little attention has been given to the importance of exchange rate exposure for the stock return generating process. This paper offers a comprehensive study of the relation between foreign exchange rate exposures and stock returns based on a large sample of non-financial firms from 37 countries around the world including the United States. The analysis is motivated by the observation that the existing literature has often perceived it as surprising that the stock returns of only few non-financial firms are affected by exchange rates and that there is little evidence on whether exchange rate changes have a systematic effect on returns, and if so how large this effect is.

The results suggest that there are noticeable differences in the effect of exchange rates on the returns of firms across countries. In particular, 30\% - 40\% of firms in open and emerging market countries such as Brazil, South Africa, Indonesia, Argentina and Thailand are significantly exposed to foreign exchange rate risk. More importantly, we document that while there does not appear to exist an unconditional relation between exchange rate exposure and stock returns, such a 
relation does exist on a conditional basis, where the conditioning variable is the realized change in the exchange rate itself. The economic magnitude of this relation is significant, ranging from just over 1\% to $3 \%$ per unit of exposure for local currency appreciations and depreciations respectively. The relation is more significant amongst emerging market firms, but present to a lesser degree for firm in developed markets as well (especially for local currency depreciations). The average return premium in emerging markets is nearly $8 \%$ per unit of exposure for local currency depreciations and $-5.5 \%$ per unit exposure for local currency appreciations. For developed markets, the return premium averages only $2.5 \%$ per unit of exposure for local currency depreciations and is not significantly apparent for local currency appreciations.

Given the increasing trend of globalization of business activities, these results have important implications for asset pricing, corporate finance and risk management. They suggest that investors should be cognizant of the fact that exchange rates are an important risk factor for firms and that this risk factor translates into non-trivial conditional return premia in most cases. While exchange rate changes are close to random, the impact of exchange rates on firm returns is unconditionally close to zero. However, the estimates of exchange rate exposure and the realization of the exchange rate index have consistent and predictable impacts on returns. From an economics standpoint, the paper demonstrates that exchange rate exposure is an important, systematic variable in the return generating process. While the impact of exchange rates on returns could in principle stem from an effect on the firms' cash flows or discount rate, we show that the effect of exchange rate risk on stock returns must predominantly, if not exclusively, be an effect on the cash flows of a firm. 


\section{References}

Adler, M., and B. Dumas 1984. Exposure to Currency Risk: Definition and Measurement. Financial Management 13:2: 41-50.

Allayannis, G. and E. Ofek, 2001. Exchange Rate Exposure, Hedging, and the Use of Foreign Currency Derivatives. Journal of International Money and Finance 20: 273-296.

Allayannis, G., and J. Ihrig, 2001. Exposure and markups, Review of Financial Studies 14:3: 805-835.

Allayannis, G., J. Ihrig, and J.P. Weston 2001, Exchange-rate hedging: Financial versus operational strategies. The American Economic Review 91:2: 391-395.

Aretz, K., S.M. Bartram, and P.F. Pope 2005. Macroeconomic Risks and Characteristic-Based Factor Models. Lancaster University Working Paper.

Bailey, W. and Y.P. Chung 1995. Exchange rate fluctuations, political risk, and stock returns: Some evidence from an emerging market. Journal of Financial and Quantitative Analysis 30:4: 541560.

Bartov, E., and G.M. Bodnar 1994. Firm Valuation, Earnings Expectations, and the Exchange Rate Exposure Effect. Journal of Finance 44:5: 1755-1785.

Bartov, E., G.M. Bodnar, and A. Kaul 1996. Exchange Rate Variability and the Riskiness of U.S. Multinational Firms: Evidence from the Breakdown of the Bretton Woods System. Journal of Financial Economics 42:1: 105-132.

Bartram, S.M., and G.A. Karolyi 2006. The Impact of the Introduction of the Euro on Foreign Exchange Rate Risk Exposures. Journal of Empirical Finance 13:4-5: 519-549.

Bartram, S.M., and G.M. Bodnar 2007. The Exchange Rate Exposure Puzzle. Managerial Finance Vol. 33 (9), September, 642-666.

Bartram, S.M., N. Burns, and J. Helwege 2007. Foreign Currency Exposure and Hedging: Evidence from Foreign Acquisitions. Lancaster University, University of Texas at San Antonio and Penn State University Working Paper.

Bekaert, G. and C.R. Harvey 2000. Foreign Speculators and Emerging Equity Markets. Journal of Finance 55:2: 565-613.

Bodnar, G.M., and F. M. H. Wong 2003. Estimating Exchange Rate Exposures: Issues is Model Structure. Financial Management, 32:1, 35-67.

Bodnar, G.M., and W.M. Gentry 1993. Exchange Rate Exposure and Industry Characteristics: Evidence from Canada, Japan, and the USA. Journal of International Money and Finance 12:1, $29-45$.

Brennan, M. J. and Y. Xia 2006. International Capital Markets and Foreign Exchange Risk. The Review of Financial Studies 19:3: 753-795.

Brennan, M.J., T. Chordia, and A. Subrahmanyam 1998. Alternative factor specifications, security characteristics, and the cross-section of expected stock returns. Journal of Financial Economics 49: 345-373. 
Brown, S.J., and T. Otsuki 1990. Macroeconomic Factors and the Japanese Equity Markets: The CAPMD Project, in: Elton, E.J., and M.J. Gruber [eds.]: Japanese Capital Markets, Harper and Row (New York, NY), 175-192.

Cappiello, L., O. Castren, and J. Jaaskela 2003. Measuring the Euro exchange rate risk premium: The conditional International CAPM approach. European Central Bank Working Paper.

Carrieri, F. 2001. The effects of liberalization on market and currency risk in the EU. European Financial Management 7: 259-290.

Carrieri, F., and B. Majerbi 2005. The Pricing of Exchange Rate Risk in Emerging Stock Markets. McGill University Working Paper.

Carrieri, F., V.R. Errunza, and B. Majerbi 2003. Global price of foreign exchange rate risk. McGill University Working Paper.

Choi, J.J., and A.M. Prasad 1995. Exchange Risk Sensitivity and Its Determinants: A Firm and Industry Analysis of U.S. Multinationals. Financial Management 24:3: 77-88.

Choi, J.J., E. Elyasiani, E., and K.J. Kopecky 1992. The Sensitivity of Bank Returns to Market, Interest and Exchange Rate Risk. Journal of Banking and Finance 16:5: 983-1004.

Choi, J.J., T. Hiraki, and N. Takezawa 1998. Is foreign exchange rate risk priced in the Japanese stock market? Journal of Financial and Quantitative Analysis 33:3: 361-382.

Chow, E.H., W.Y. Lee, and M.E. Solt 1997. The exchange rate risk exposure of asset returns. Journal of Business 70:1: 107-123.

Cooper, I. 2007. On tests of the conditional relationship between beta and returns. Applied Financial Economics, forthcoming.

De Santis, G. and B. Gerard 1997. International Asset Pricing and Portfolio Diversification with Time-varying Risk. Journal of Finance 52:5: 1881-1912.

De Santis, G. and B. Gerard 1998. How big is the premium for currency risk? Journal of Financial Economics 49: 375-412.

Doidge, C., J. Griffin and R. Williamson 2006. Measuring the economic importance of exchange rate exposure. Journal of Empirical Finance 13: 550-576.

Dominguez, K.M.E. 1987. Exchange-Rate Efficiency and the Behavior of International Asset Markets, UMI (Ann Arbor, MI).

Dominguez, K.M.E., and L.L. Tesar 2001a. A reexamination of exchange-rate exposure. American Economic Review 91:2: 396-400.

Dominguez, K.M.E., and L.L. Tesar 2001b. Trade and Exposure, American Economic Review 91:2: 367-370.

Dominguez, K.M.E., and L.L. Tesar 2006. Exchange Rate Exposure, Journal of International Economics 68:1: 188-218.

Doukas, J., P.H. Hall, and L.H.P Lang 1999. The Pricing of Currency Risk in Japan. Journal of Banking and Finance 23:1: 1-20.

Dukas, S.P., A.M. Fatemi, and A. Tavakkol 1996. Foreign Exchange Rate Exposure and the Pricing of Exchange Rate Risk. Global Finance Journal 7:2: 169-189. 
Dumas, B., and B. Solnik 1995. The World Price of Foreign Exchange Rate Risk. Journal of Finance 50:2: 445-479.

Eun, C.S., and B.G. Resnick 1988. Exchange Rate Uncertainty, Forward Contracts, and International Portfolio Selection. Journal of Finance 43:1: 197-215.

Fama, E. F., and J. MacBeth 1973. Risk, Return and Equilibrium: Empirical tests. Journal of Political Economy 81: 607-636.

Francis, B.B., I. Hasan, and D. M. Hunter 2007. Can hedging tell the full story? Reconciling differences in U.S. aggregate-and-industry-level exchange rate exposures, Journal of Financial Economics, forthcoming.

Frankel, J.A. and M. Chinn 1993. Exchange Rate Expectations and the Risk Premium Test for a Cross-section of 17 Currencies, NBER Working Paper 3806.

Froot, K.A. and J.A. Frankel 1989. Forward Discount Bias: Is it an Exchange Risk Premium? Quarterly Journal of Economics 104:1: 139-161.

Giovannini, A. and P. Jorion 1989. The time-variation of risk and return in the foreign exchange and stock markets. Journal of Finance 44: 307-325.

Gopinath, G., O. Itskhoki and R. Rigobon, 2006. Pass-through at the Dock: Pricing to Currency and to Market. MIT Working Paper.

Griffin, J.M., and R.M. Stulz 2001. International Competition and Exchange Rate Shocks: A CrossCountry Industry Analysis of Stock Returns. Review of Financial Studies 14:1: 215-241.

Groen, J.J.J. and R. Balakrishnan 2006. Asset Price Based Estimates of Sterling Exchange Rate Risk Premia. Journal of International Money and Finance 3:2: 123-192.

Gupta, M. and J.E. Finnerty 1992. The Currency Risk Factor in International Equity Pricing. Review of Quantitative Finance and Accounting 2:3: 245-257.

Hamao. Y. 1988. An Empirical Examination of the Arbitrage Pricing Theory. Japan, and the World Economy 1:1: 45-61.

Hau, H. and H. Rey 2005. Exchange Rates, Equity Prices, and Capital Flows. Review of Financial Studies 19:1: 273-317.

He, J., and L.K. Ng 1998. The Foreign Exchange Exposure of Japanese Multinational Corporations. Journal of Finance 53:2: 733-753.

Jorion, P. 1990. The Exchange-Rate Exposure of U.S. Multinationals. Journal of Business 63:3: 331345.

Jorion, P. 1991. The Pricing of Exchange Rate Risk in the Stock Market. Journal of Financial and Quantitative Analysis 26:3: 363-376.

Kan, R and G. Zhou 1999. A Critique of Stochastic Discount Factor Methodology. Journal of Finance 54:4: 1221-1248.

Kolari, J.W., T.C. Moorman and S.M. Sorescu 2005. Foreign Exchange Risk and the Cross-Section of Stock Returns. Texas A\&M Working Paper.

Korajczyk, R.A. and C.J. Viallet 1989. An Empirical Investigation of International Asset Pricing. Review of Financial Studies 2:4: 553-585. 
Lakonishok, J., and A. Shapiro 1984. Stock Returns, Beta, Variance and Size: An Empirical Analysis. Financial Analysts Journal 40: 36-41.

Levine, R. and S.L. Schmukler 2006. Internationalization and Stock Market Liquidity. Review of Finance 10:1: 153-187.

Llorente, G., R. Michaely, G. Saar, and J. Wang 2001. Dynamic Volume-Return Relation of Individual Stocks. Review of Financial Studies 15: 1005-10047.

Loudon, G.F. 1993. The Foreign Exchange Operating Exposure of Australian Stocks. Accounting and Finance 33:1: 19-32.

Naik, N.Y. and P.K. Yadav 2003. Do dealer firms manage inventory on a stock-by-stock or a portfolio basis? Journal of Financial Economics 69: 325-353.

Newey, W.K., and K.D. West 1987. A simple, positive semi-definite, heteroskedasticity and autocorrelation consistent covariance matrix. Econometrica 55: 3: 703-708.

Odders-White, E.R. and M.J. Ready 2004. Credit ratings and stock liquidity. Working Paper, University of Madison-Wisconsin.

Pettengill, G.N., S. Sundaram and I. Mathur 1995. The Conditional Relation between Beta and Returns. Journal of Financial and Quantitative Analysis 30:1: 101-116.

Phylaktis, K. and F. Ravazzolo 2002. Currency risk in emerging equity markets. Working Paper Cass Business School, London.

Prasad, A.M., and M. Rajan 1995. The Role of Exchange and Interest Risk in Equity Valuation: A Comparative Study of International Stock Markets. Journal of Economics and Business 47:5: 457-472.

Roache, S.K., and M.D. Merritt 2006. Currency Risk Premia in Global Stock Markets. IMF Working Paper.

Shanken, J. 1992. On the Estimation of Beta-Pricing Models. Review of Financial Studies 5:1: 1-33.

Vassalou, M. 2000. Exchange rate and foreign inflation risk premia in global equity returns. Journal of International Money and Finance 19: 433-470.

Wang, A.T. and S.-Y. Yang 2004. Foreign Exchange Risk, World Diversification, and Taiwanese ADRs. Applied Economics Letters 11:12: 755-758.

Williamson, R. 2001, Exchange rate exposure and competition: evidence from the automotive industry. Journal of Financial Economics 59:3: 441-475. 


\section{Figure 1: Predicted Relation between Exchange Rate Exposure and Stock Returns}

The figure shows the predicted relation between stock returns and foreign exchange rate exposure, separately for local currency appreciation and depreciation.

\section{Return}

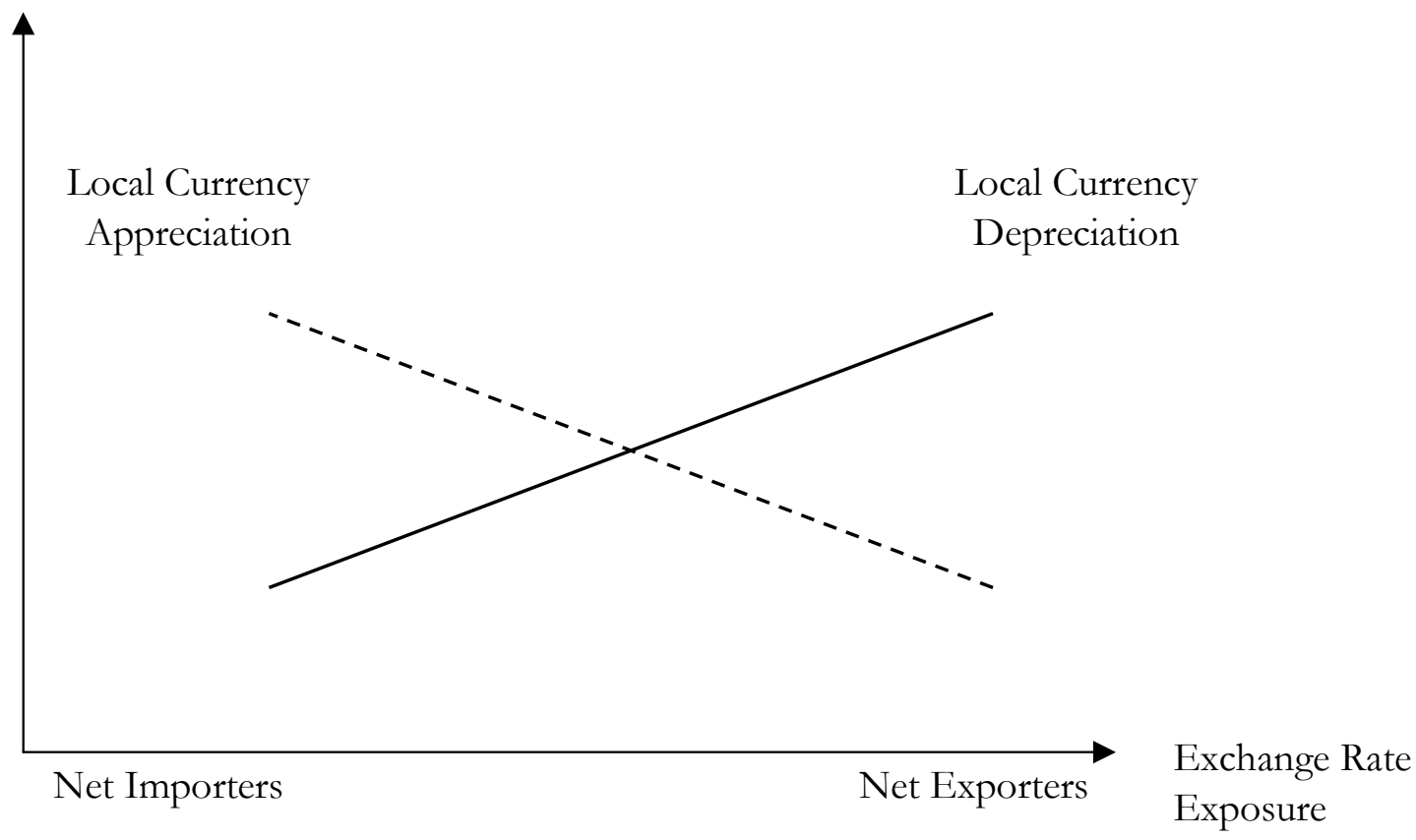




\section{Figure 2: Actual Relation between Exchange Rate Exposure and Stock Returns}

The figure shows the actual relation between portfolio returns and foreign exchange rate exposure, separately for local currency appreciation and depreciation. Panel A shows plots for all firms while Panel B shoes the results separately for Emerging market and Developed market firms. Returns displayed are adjusted portfolio returns (i.e. returns net of alpha and the market return times beta). Firms are sorted each month on the basis of their exposure into quintiles of foreign exchange rate exposures from low/negative (net importers in portfolio 1) to high/positive (net exporters in portfolio 5). Results are shown for different subsamples, i.e. firms in all countries, firms in 14 Emerging market countries (Argentina, Brazil, Chile, India, Indonesia, Korea, Malaysia, Mexico, Peru, Philippines, South Africa, Thailand, Turkey, Venezuela), and firms in 23 developed market countries (Australia, Austria, Belgium, Denmark, Finland, France, Germany, Greece, Hong Kong, Ireland, Italy, Japan, Netherlands, New Zealand, Norway, Portugal, Singapore, Spain, Sweden, Switzerland, UK, the United States).

\section{Panel A: All Firms}

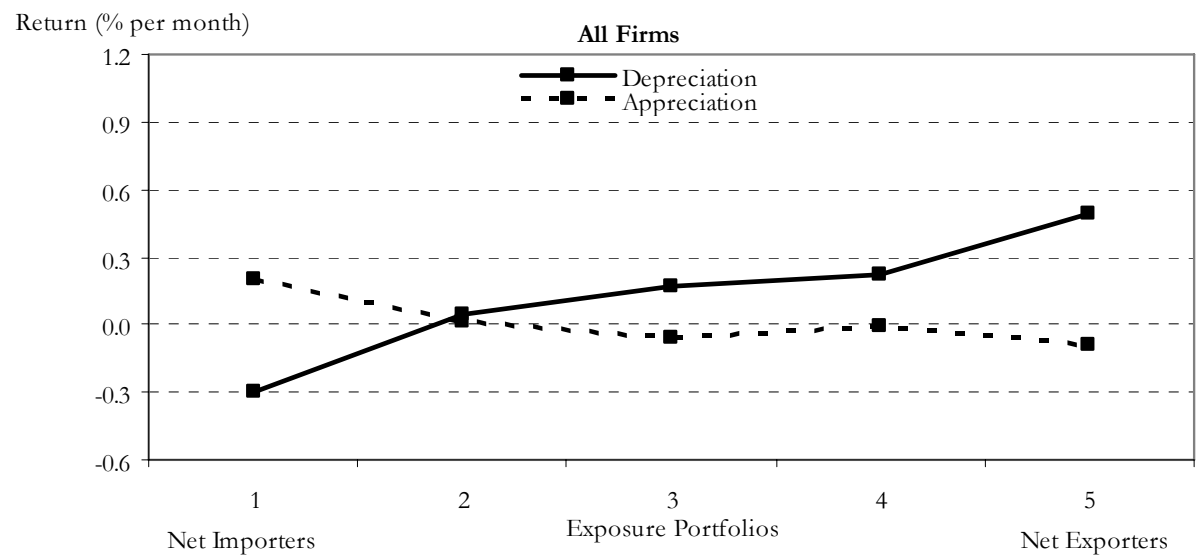

Panel B: Emerging and Developed Market Firms
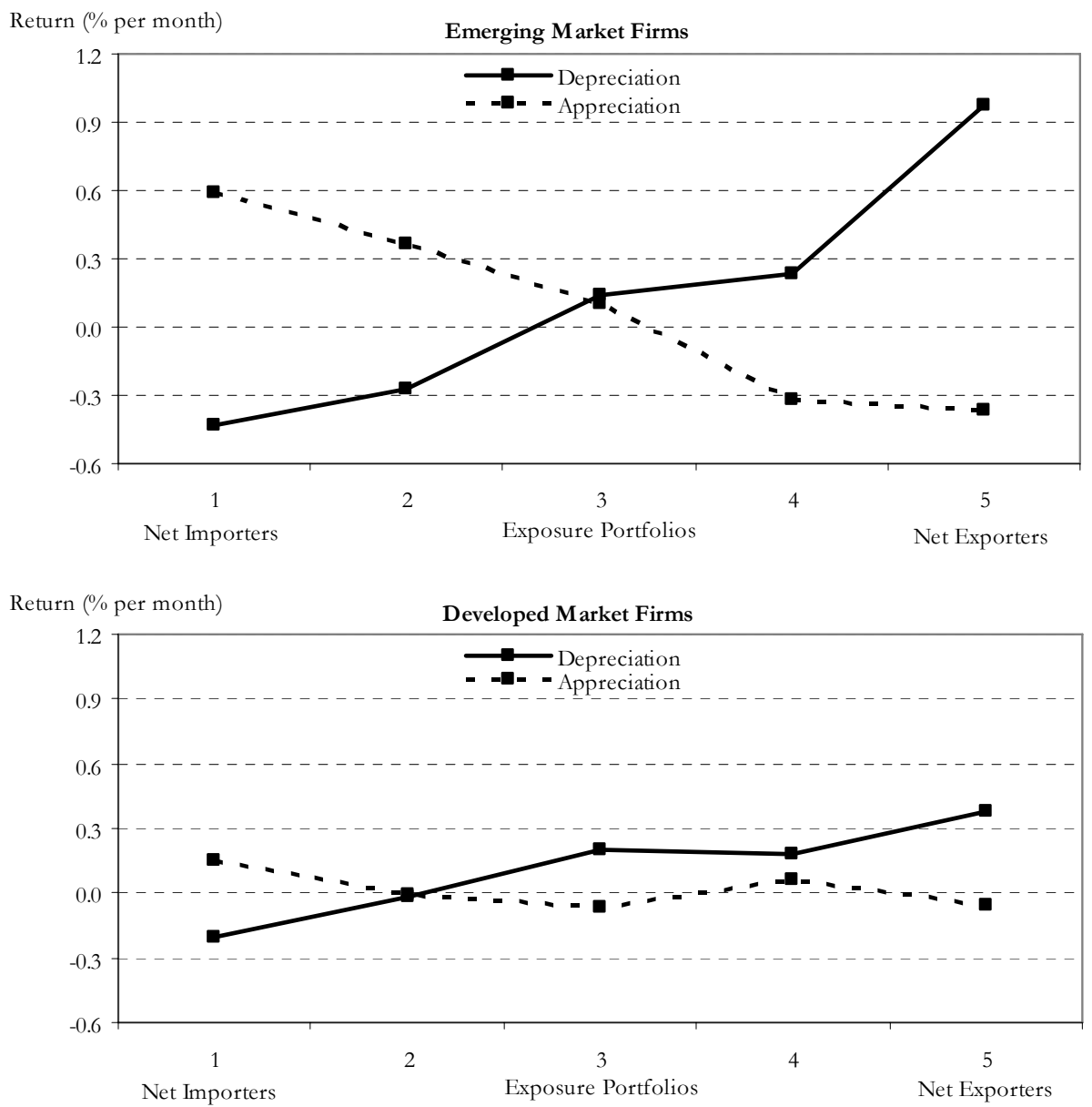


\section{Table 1: Descriptive Sample Statistics}

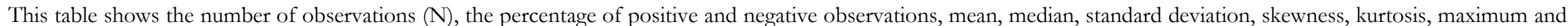

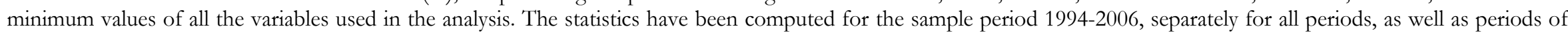

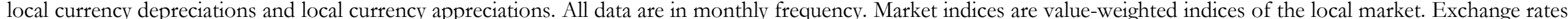

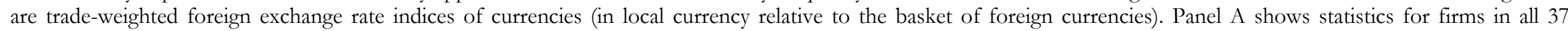

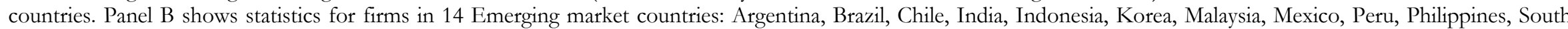

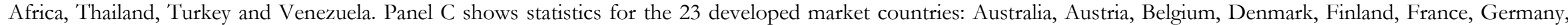
Greece, Hong Kong, Ireland, Italy, Japan, Netherlands, New Zealand, Norway, Portugal, Singapore, Spain, Sweden, Switzerland, UK, and the United States.

\begin{tabular}{|c|c|c|c|c|c|c|c|c|c|c|}
\hline & \multirow[b]{2}{*}{$\mathrm{N}$} & \multicolumn{2}{|c|}{ Percentage } & \multirow[b]{2}{*}{ Mean } & \multirow[b]{2}{*}{ Median } & \multirow[b]{2}{*}{ Std. Dev. } & \multirow[b]{2}{*}{ Skewness } & \multirow[b]{2}{*}{ Kurtosis } & \multirow[b]{2}{*}{ Minimum } & \multirow[b]{2}{*}{ Maximun } \\
\hline & & positive & negative & & & & & & & \\
\hline \multicolumn{11}{|l|}{ Panel A: All firms (37 countries) } \\
\hline \multicolumn{11}{|l|}{ All Periods } \\
\hline Stock returns & 591,949 & 55.6 & 44.4 & 0.86 & 0.71 & 11.70 & -0.01 & 5.06 & -63.68 & 65.48 \\
\hline Market indices & 591,949 & 61.0 & 39.0 & 0.80 & 1.30 & 5.67 & -0.30 & 5.56 & -50.16 & 57.96 \\
\hline Exchange rates & 591,949 & 51.8 & 48.2 & 0.08 & 0.01 & 2.50 & 3.36 & 71.75 & -29.53 & 64.47 \\
\hline \multicolumn{11}{|l|}{ Local Currency Depreciation } \\
\hline Stock returns & 306,863 & 56.4 & 43.6 & 0.97 & 0.84 & 11.61 & -0.04 & 5.09 & -63.68 & 65.48 \\
\hline Market indices & 306,863 & 61.1 & 38.9 & 0.88 & 1.30 & 5.65 & -0.28 & 8.04 & -50.16 & 57.96 \\
\hline Exchange rates & 306,863 & 100.0 & & 1.49 & 0.92 & 2.28 & 9.61 & 165.02 & 0.00 & 64.47 \\
\hline \multicolumn{11}{|l|}{ Local Currency Appreciation } \\
\hline Stock returns & 285,086 & 54.8 & 45.2 & 0.73 & 0.57 & 11.80 & 0.03 & 5.03 & -63.68 & 65.48 \\
\hline Market indices & 285,086 & 60.9 & 39.1 & 0.71 & 1.30 & 5.70 & -0.32 & 3.00 & -36.20 & 42.89 \\
\hline Exchange rates & 285,086 & & 100.0 & -1.44 & -0.97 & 1.73 & -4.25 & 31.00 & -29.53 & -0.01 \\
\hline
\end{tabular}


Table 1: Descriptive Sample Statistics (continued)

\begin{tabular}{|c|c|c|c|c|c|c|c|c|c|c|}
\hline & \multirow[b]{2}{*}{$\mathrm{N}$} & \multicolumn{2}{|c|}{ Percentage } & \multirow[b]{2}{*}{ Mean } & \multirow[b]{2}{*}{ Median } & \multirow[b]{2}{*}{ Std. Dev. } & \multirow[b]{2}{*}{ Skewness } & \multirow[b]{2}{*}{ Kurtosis } & \multirow[b]{2}{*}{ Minimum } & \multirow[b]{2}{*}{ Maximum } \\
\hline & & positive & negative & & & & & & & \\
\hline \multicolumn{11}{|c|}{ Panel B: Emerging market firms (14 countries) } \\
\hline \multicolumn{11}{|c|}{ All Periods } \\
\hline Stock returns & 92,351 & 56.3 & 43.7 & 1.16 & 0.49 & 14.32 & 0.15 & 3.70 & -63.68 & 65.48 \\
\hline Market indices & 92,351 & 58.7 & 41.3 & 1.17 & 1.48 & 8.59 & -0.05 & 4.28 & -50.16 & 57.96 \\
\hline Exchange rates & 92,351 & 52.3 & 47.7 & 0.44 & 0.08 & 4.42 & 4.07 & 42.82 & -29.53 & 64.47 \\
\hline \multicolumn{11}{|l|}{ Local Currency Depreciation } \\
\hline Stock returns & 48,334 & 52.8 & 47.2 & -0.04 & 0.00 & 14.80 & 0.00 & 3.46 & -63.68 & 65.48 \\
\hline Market indices & 48,334 & 52.8 & 47.2 & 0.06 & 0.36 & 9.24 & -0.01 & 4.82 & -50.16 & 57.96 \\
\hline Exchange rates & 48,334 & 100.0 & & 2.57 & 1.25 & 4.71 & 6.05 & 49.40 & 0.00 & 64.47 \\
\hline \multicolumn{11}{|l|}{ Local Currency Appreciation } \\
\hline Stock returns & 44,017 & 60.2 & 39.8 & 2.49 & 1.41 & 13.65 & 0.43 & 3.93 & -63.68 & 65.48 \\
\hline Market indices & 44,017 & 65.1 & 34.9 & 2.37 & 2.44 & 7.63 & 0.09 & 2.61 & -36.20 & 42.89 \\
\hline Exchange rates & 44,017 & & 100.0 & -1.90 & -1.23 & 2.50 & -4.10 & 24.76 & -29.53 & -0.01 \\
\hline \multicolumn{11}{|c|}{ Panel C: Developed market firms (23 countries) } \\
\hline \multicolumn{11}{|c|}{ All Periods } \\
\hline Stock returns & 499,598 & 55.5 & 44.5 & 0.80 & 0.74 & 11.15 & -0.08 & 5.21 & -63.68 & 65.48 \\
\hline Market indices & 499,598 & 61.4 & 38.6 & 0.73 & 1.30 & 4.95 & -0.56 & 2.29 & -34.50 & 34.52 \\
\hline Exchange rates & 499,598 & 51.7 & 48.3 & 0.02 & 0.00 & 1.95 & -0.77 & 7.70 & -15.22 & 8.71 \\
\hline \multicolumn{11}{|l|}{ Local Currency Depreciation } \\
\hline Stock returns & 258,529 & 57.1 & 42.9 & 1.16 & 1.02 & 10.90 & -0.01 & 5.24 & -63.68 & 65.48 \\
\hline Market indices & 258,529 & 62.7 & 37.3 & 1.03 & 1.41 & 4.66 & -0.28 & 2.50 & -32.71 & 34.52 \\
\hline Exchange rates & 258,529 & 100.0 & & 1.29 & 0.86 & 1.33 & 1.83 & 4.29 & 0.00 & 8.71 \\
\hline \multicolumn{11}{|l|}{ Local Currency Appreciation } \\
\hline Stock returns & 241,069 & 53.8 & 46.2 & 0.41 & 0.44 & 11.40 & -0.14 & 5.16 & -63.68 & 65.48 \\
\hline Market indices & 241,069 & 60.1 & 39.9 & 0.41 & 1.13 & 5.22 & -0.74 & 1.94 & -34.50 & 22.24 \\
\hline Exchange rates & 241,069 & & 100.0 & -1.35 & -0.92 & 1.54 & -3.71 & 23.24 & -15.22 & -0.01 \\
\hline
\end{tabular}




\section{Table 2: Foreign Exchange Rate Exposures}

The table shows results of regressions of returns on the value-weighted market index and the exchange rate index on the stock returns of non-financial firms. Regressions are estimated over rolling windows of 60 consecutive months. Standard errors are corrected for autocorrelation and heteroskedasticity with the Newey-West procedure. Panel A reports statistics on the coefficients of the intercept, market index and the exchange rate variable. In particular, the average positive and negative coefficient, the average significant positive and negative coefficient (5\% level), as well as the percentage of positive and negative coefficients that are significant at the $5 \%$ level are reported. Panel B reports by country the percentage of firms with significant exposure (5\% level), the median and mean exposure, as well as $p$-values of tests that the mean exposure is equal to zero. Countries are sorted by their percentage of significant exposures from low to high. ${ }^{*}, *$ and $* * *$ indicate significance at the 10,5 and 1 percent significance level, respectively.

\section{Panel A: Summary Statistics of Regression Estimates}

\begin{tabular}{|c|c|c|c|c|c|c|}
\hline & \multicolumn{2}{|c|}{ Mean coefficient } & \multicolumn{2}{|c|}{ Mean sig. coefficient } & \multicolumn{2}{|c|}{$\%$ sig. coefficients } \\
\hline & positive & negative & positive & negative & positive & negative \\
\hline Exchange rate & 0.839 & -0.799 & 1.756 & -1.676 & 6.4 & 5.0 \\
\hline Market index & 0.893 & -0.125 & 1.049 & -0.373 & 75.3 & 0.0 \\
\hline Intercept & 1.167 & -1.083 & 2.382 & -3.262 & 8.2 & 2.1 \\
\hline
\end{tabular}

(continued) 
Table 2: Foreign Exchange Rate Exposures (continued)

Panel B: Foreign Exchange Rate Exposures by Country

\begin{tabular}{|c|c|c|c|c|}
\hline & \multicolumn{4}{|c|}{ Exposure estimate } \\
\hline & $\%$ significant & Median & Mean & $p$-value \\
\hline \multicolumn{5}{|c|}{ Low fraction of firms with significant exposure } \\
\hline Portugal & 6.2 & 0.198 & 0.276 & $<0.001$ \\
\hline New Zealand & 6.3 & -0.077 & -0.102 & $<0.001$ \\
\hline Peru & 6.6 & -0.048 & -0.084 & 0.003 \\
\hline Spain & 6.6 & 0.154 & 0.123 & $<0.001$ \\
\hline France & 7.3 & 0.107 & 0.057 & $<0.001$ \\
\hline Austria & 7.4 & 0.056 & 0.219 & $<0.001$ \\
\hline Sweden & 7.7 & 0.181 & 0.152 & $<0.001$ \\
\hline Finland & 7.9 & 0.787 & 0.702 & $<0.001$ \\
\hline United States & 8.1 & 0.038 & 0.048 & $<0.001$ \\
\hline Canada & 8.2 & -0.155 & -0.350 & $<0.001$ \\
\hline \multicolumn{5}{|c|}{ Medium fraction of firms with significant exposure } \\
\hline Chile & 8.3 & -0.103 & -0.113 & $<0.001$ \\
\hline India & 8.5 & 0.464 & 0.530 & $<0.001$ \\
\hline Belgium & 8.7 & 0.175 & 0.299 & $<0.001$ \\
\hline Hong Kong & 8.7 & 0.624 & 0.620 & $<0.001$ \\
\hline Netherlands & 8.8 & -0.117 & -0.284 & $<0.001$ \\
\hline Switzerland & 9.4 & 0.580 & 0.700 & $<0.001$ \\
\hline Australia & 9.5 & -0.093 & -0.106 & $<0.001$ \\
\hline Germany & 9.6 & 0.234 & 0.164 & $<0.001$ \\
\hline United Kingdom & 9.9 & 0.093 & 0.038 & $<0.001$ \\
\hline Italy & 10.2 & 0.613 & 0.873 & $<0.001$ \\
\hline Singapore & 10.3 & -0.180 & -0.064 & 0.008 \\
\hline Denmark & 10.7 & 0.443 & 0.510 & $<0.001$ \\
\hline Japan & 11.1 & 0.038 & 0.016 & $<0.001$ \\
\hline Ireland & 11.5 & 0.250 & 0.384 & $<0.001$ \\
\hline Norway & 13.8 & 0.009 & 0.084 & $<0.001$ \\
\hline Malaysia & 15.5 & 0.025 & -0.097 & $<0.001$ \\
\hline Philippines & 15.5 & -0.077 & -0.214 & $<0.001$ \\
\hline \multicolumn{5}{|c|}{ High fraction of firms with significant exposure } \\
\hline Greece & 18.0 & -0.478 & -0.687 & $<0.001$ \\
\hline Mexico & 19.1 & -0.201 & -0.206 & $<0.001$ \\
\hline Venezuela & 20.3 & -0.056 & -0.081 & $<0.001$ \\
\hline Korea & 23.6 & -0.207 & -0.115 & $<0.001$ \\
\hline Turkey & 27.6 & -0.053 & -0.148 & $<0.001$ \\
\hline Thailand & 27.6 & -0.403 & -0.519 & $<0.001$ \\
\hline Argentina & 31.9 & 0.139 & 0.201 & $<0.001$ \\
\hline Indonesia & 35.3 & -0.138 & -0.209 & $<0.001$ \\
\hline South Africa & 36.3 & -0.225 & -0.175 & $<0.001$ \\
\hline Brazil & 39.4 & -0.111 & -0.102 & $<0.001$ \\
\hline
\end{tabular}




\section{Table 3: Exchange Rate Return Premia}

The table shows results of cross-sectional regressions of market betas and exchange rate exposure on stock returns in the following month (Fama-MacBeth, 1973). Market betas and exchange rate exposure are estimated in rolling window time-series regressions of the value-weighted market index and the exchange rate index on the stock returns of non-financial firms. The table shows the mean coefficients (return premium) for each factor or factor interaction and corresponding $p$-values as well as the number of observations (N). Standard errors are corrected with the Newey-West (1987) procedure. Panel A shows the unconditional mean coefficient on the factor loadings as well as the mean coefficients. Panel B shows the same mean coefficients but conditional on whether the local currency appreciated or depreciated during the return premium determination month. Panel $\mathrm{C}$ shows the mean coefficients when the return premium for the exchange rate exposure is modeled as a constant plus the contemporaneous return on the exchange rate factor and the return premium for the market beta is modeled as a constant plus the contemporaneous return on the market portfolio in that country as specified in $\mathrm{Eq}(3)$. Results are for firms in all 37 countries.

\begin{tabular}{|c|c|c|}
\hline \multicolumn{3}{|l|}{ Panel A: All periods } \\
\hline & Coef. & $p$-value \\
\hline Exchange rate exposure & 0.027 & 0.396 \\
\hline Market beta & -0.107 & 0.124 \\
\hline Intercept & 0.033 & 0.177 \\
\hline $\mathrm{N}$ & 9 & \\
\hline
\end{tabular}

Panel B: Local currency appreciation/depreciation

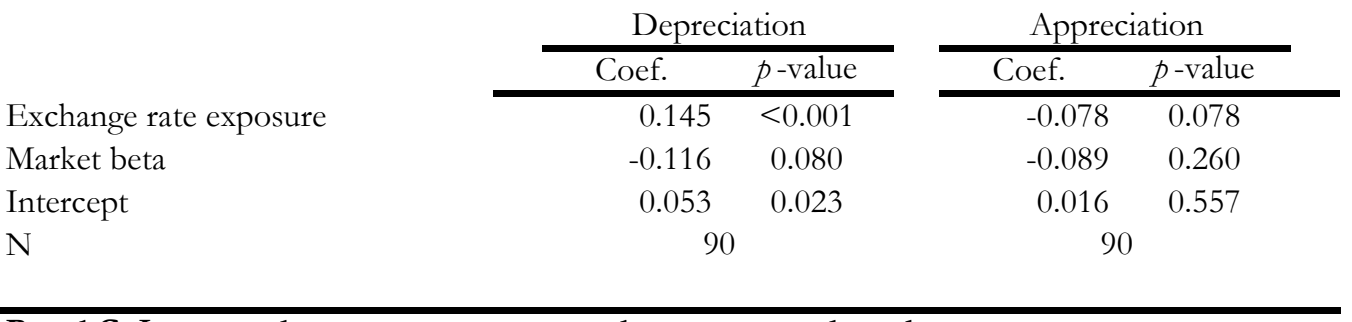

Panel C: Interacted contemporaneous exchange rate and market return

Exchange rate exposure $*$ Exchange rate return

\begin{tabular}{cr} 
Coef. & $p$-value \\
\hline 0.134 & $<0.001$ \\
0.035 & 0.211 \\
0.829 & $<0.001$ \\
-0.084 & 0.016 \\
0.035 & 0.121
\end{tabular}

Exchange rate exposure

Market beta * Market return

0.035

90 
Table 4: Returns on Exchange Rate Exposure-sorted Portfolios

The table shows average values of total portfolio returns, adjusted portfolio returns (i.e. returns net of alpha and the market return times beta) as well as foreign exchange rate exposures. Results are shown for portfolios sorted by foreign exchange rate exposure into quintiles and for a portfolio long quintile 5 and short quintile 1 (High-Low). The final column calculates the annualized return premium per unit of exchange rate exposure by annualizing the adjusted return on the High - Low portfolio and dividing by the net exposure of the high-low portfolio. Panel A shows results for local currency depreciation periods, and Panel B shows the results for local currency appreciation periods. Results are for firms in all 37 countries.

\begin{tabular}{|c|c|c|c|c|c|c|c|c|}
\hline & \multicolumn{5}{|c|}{ Exchange Rate Exposure Quintiles } & \multirow[b]{2}{*}{ High-Low } & \multirow[b]{2}{*}{$p$-value } & \multirow{2}{*}{$\begin{array}{l}\text { Annualized return } \\
\text { premium per unit of } \\
\text { depreciation exposure }\end{array}$} \\
\hline & 1 (Low) & 2 & 3 & 4 & 5 (High) & & & \\
\hline \multicolumn{9}{|c|}{ Panel A: Local currency depreciation } \\
\hline Total portfolio return & 0.764 & 1.012 & 1.091 & 1.051 & 1.316 & 0.552 & {$[0.00]$} & \multirow{3}{*}{$3.30 \%$} \\
\hline Adjusted portfolio return & -0.299 & 0.042 & 0.169 & 0.227 & 0.492 & 0.791 & {$[0.00]$} & \\
\hline Portfolio exposure & -1.378 & -0.445 & 0.054 & 0.554 & 1.497 & 2.875 & {$[0.00]$} & \\
\hline \multicolumn{9}{|c|}{ Panel B: Local Currency Appreciation } \\
\hline Total portfolio return & 0.968 & 0.813 & 0.752 & 0.750 & 0.761 & -0.207 & {$[0.28]$} & \multirow{3}{*}{$-1.15 \%$} \\
\hline Adjusted portfolio return & 0.199 & 0.009 & -0.062 & -0.005 & -0.091 & -0.290 & [0.09] & \\
\hline Portfolio exposure & -1.448 & -0.464 & 0.054 & 0.571 & 1.575 & 3.024 & {$[0.00]$} & \\
\hline
\end{tabular}




\section{Table 5: Conditional Exchange Rate Return Premia by Market Development}

Panel A shows results of cross-sectional regressions of market betas and exchange rate exposure on stock returns in the following month (Fama-MacBeth, 1973) for emerging market and developed market firms. Market betas and exchange rate exposure are estimated in rolling window time-series regressions of the value-weighted market index and the exchange rate index on the stock returns of non-financial firms. The table shows the mean coefficients (return premium) for each factor and corresponding $p$-values as well as the number of observations $(\mathrm{N})$. Standard errors are corrected with the Newey-West (1987) procedure. The table shows the unconditional mean coefficient on the factor loadings as well as the mean coefficients conditional on whether the local currency appreciated or depreciated during the return premium determination month. Panel B shows the mean coefficients when the return premium for the exchange rate exposure is modeled as a constant plus the contemporaneous return on the exchange rate factor and the return premium for the market beta is modeled as a constant plus the contemporaneous return on the market portfolio in that country as specified in Eq(3). The emerging market countries are: Argentina, Brazil, Chile, India, Indonesia, Korea, Malaysia, Mexico, Peru, Philippines, South Africa, Thailand, Turkey and Venezuela. The developed market countries are: Australia, Austria, Belgium, Denmark, Finland, France, Germany, Greece, Hong Kong, Ireland, Italy, Japan, Netherlands, New Zealand, Norway, Portugal, Singapore, Spain, Sweden, Switzerland, UK, and the United States.

\section{Panel A: Local Currency Appreciation and Depreciation}

\begin{tabular}{|c|c|c|c|c|c|c|}
\hline & \multicolumn{2}{|c|}{ All periods } & \multicolumn{2}{|c|}{$\begin{array}{c}\text { Local currency } \\
\text { depreciation }\end{array}$} & \multicolumn{2}{|c|}{$\begin{array}{c}\text { Local currency } \\
\text { appreciation }\end{array}$} \\
\hline & Coef. & $p$-value & Coef. & $p$-value & Coef. & $p$-value \\
\hline \multicolumn{7}{|l|}{ Emerging market firms (14 countries) } \\
\hline Exchange rate exposure & 0.034 & 0.339 & 0.195 & $<0.001$ & -0.170 & 0.004 \\
\hline Market beta & -0.091 & 0.083 & -0.138 & 0.030 & -0.044 & 0.504 \\
\hline Intercept & 0.041 & 0.149 & 0.038 & 0.242 & 0.044 & 0.161 \\
\hline $\mathrm{N}$ & \multicolumn{2}{|c|}{90} & \multicolumn{2}{|c|}{89} & \multicolumn{2}{|c|}{87} \\
\hline \multicolumn{7}{|c|}{ Developed market firms (23 countries) } \\
\hline Exchange rate exposure & 0.036 & 0.346 & 0.141 & 0.001 & -0.050 & 0.358 \\
\hline Market beta & -0.118 & 0.137 & -0.127 & 0.106 & -0.089 & 0.324 \\
\hline Intercept & 0.033 & 0.164 & 0.054 & 0.018 & 0.013 & 0.642 \\
\hline $\mathrm{N}$ & \multicolumn{2}{|c|}{90} & \multicolumn{2}{|c|}{90} & \multicolumn{2}{|c|}{90} \\
\hline
\end{tabular}

\section{Panel B: Interacted Contemporaneous Exchange Rate and Market Return}

\begin{tabular}{lrr}
\hline & Coef. & \multicolumn{1}{c}{$p$-value } \\
\hline Emerging market firms (14 countries) & & \\
Exchange rate exposure * Exchange rate return & 0.180 & $<0.001$ \\
Exchange rate exposure & -0.028 & 0.396 \\
Market beta * Market return & 0.843 & $<0.001$ \\
Market beta & -0.085 & 0.036 \\
Intercept & 0.048 & 0.057 \\
N & & \\
& & \\
Developed market firms (23 countries) & 0.123 & 0.003 \\
Exchange rate exposure * Exchange rate return & 0.060 & 0.123 \\
Exchange rate exposure & 0.811 & $<0.001$ \\
Market beta $*$ Market return & -0.096 & 0.011 \\
Market beta & 0.034 & 0.140 \\
Intercept & \multicolumn{2}{c}{90} \\
N & & \\
\hline
\end{tabular}




\section{Table 6: Returns on Exposure-sorted Portfolios by Market Development}

The table shows average values of total portfolio returns, adjusted portfolio returns (i.e. returns net of alpha and the market return times beta) as well as foreign exchange rate exposures. Results are shown for portfolios sorted by foreign exchange rate exposure into quintiles and for a portfolio long quintile 5 and short quintile 1 (High-Low). The final column calculates the annualized return premium per unit of exchange rate exposure by annualizing the adjusted return on the High - Low portfolio and dividing by the exposure of that portfolio. Panel A shows results for local currency depreciation periods, while Panel B shows results for local currency appreciation periods. The emerging market countries are: Argentina, Brazil, Chile, India, Indonesia, Korea, Malaysia, Mexico, Peru, Philippines, South Africa, Thailand, Turkey and Venezuela. The developed market countries are: Australia, Austria, Belgium, Denmark, Finland, France, Germany, Greece, Hong Kong, Ireland, Italy, Japan, Netherlands, New Zealand, Norway, Portugal, Singapore, Spain, Sweden, Switzerland, UK, and the United States.

\begin{tabular}{|c|c|c|c|c|c|c|c|c|c|}
\hline & & \multicolumn{5}{|c|}{ Exchange Rate Exposure Quintiles } & \multirow[b]{2}{*}{ High-Low } & \multirow[b]{2}{*}{$p$-value } & \multirow{2}{*}{$\begin{array}{l}\text { Annualized return } \\
\text { premium per unit of } \\
\text { depreciation exposure }\end{array}$} \\
\hline & & 1 (Low) & 2 & 3 & 4 & 5 (High) & & & \\
\hline \multicolumn{10}{|c|}{ Panel A: Local currency depreciation } \\
\hline \multirow{3}{*}{$\begin{array}{l}\text { Emerging } \\
\text { market firms }\end{array}$} & Total portfolio return & 0.603 & 1.371 & 1.540 & 1.675 & 2.143 & 1.540 & {$[0.00]$} & \\
\hline & Adjusted portfolio return & -0.434 & -0.268 & 0.137 & 0.238 & 0.977 & 1.411 & {$[0.00]$} & $7.99 \%$ \\
\hline & Portfolio exposure & -1.138 & -0.476 & -0.091 & 0.332 & 0.981 & 2.119 & {$[0.00]$} & \\
\hline \multirow{3}{*}{$\begin{array}{l}\text { Developed } \\
\text { market firms }\end{array}$} & Total portfolio return & 0.893 & 0.910 & 1.095 & 0.992 & 1.148 & 0.255 & {$[0.16]$} & \\
\hline & Adjusted portfolio return & -0.200 & -0.021 & 0.202 & 0.185 & 0.378 & 0.578 & {$[0.00]$} & $2.29 \%$ \\
\hline & Portfolio exposure & -1.441 & -0.417 & 0.082 & 0.587 & 1.591 & 3.032 & {$[0.00]$} & \\
\hline \multicolumn{10}{|c|}{ Panel B: Local Currency Appreciation } \\
\hline \multirow{3}{*}{$\begin{array}{l}\text { Emerging } \\
\text { market firms }\end{array}$} & Total portfolio return & 2.554 & 2.146 & 1.949 & 1.319 & 1.314 & -1.240 & [0.01] & \\
\hline & Adjusted portfolio return & 0.593 & 0.367 & 0.106 & -0.321 & -0.362 & -0.955 & {$[0.03]$} & $-5.53 \%$ \\
\hline & Portfolio exposure & -1.090 & -0.477 & -0.094 & 0.314 & 0.984 & 2.074 & {$[0.00]$} & \\
\hline \multirow{3}{*}{$\begin{array}{l}\text { Developed } \\
\text { market firms }\end{array}$} & Total portfolio return & 0.623 & 0.622 & 0.597 & 0.683 & 0.621 & -0.002 & {$[0.99]$} & \\
\hline & Adjusted portfolio return & 0.147 & -0.010 & -0.064 & 0.062 & -0.054 & -0.201 & {$[0.37]$} & $-0.75 \%$ \\
\hline & Portfolio exposure & -1.542 & -0.440 & 0.080 & 0.604 & 1.690 & 3.232 & {$[0.00]$} & \\
\hline
\end{tabular}




\section{Table 7: Characteristics of Emerging and Developed Markets}

The table shows means and medians of selected characteristics of emerging and developed market countries. In particular, it shows exports of goods and services ( $\%$ of GDP), imports of goods and services ( $\%$ of GDP), market capitalization of listed companies ( $\%$ of GDP), domestic credit to private sector ( $\%$ of GDP), daily average OTC foreign exchange derivatives turnover of local currency net of local inter-dealer doublecounting ( $\%$ of GDP), and daily average OTC single currency interest rate derivatives turnover net of local inter-dealer double-counting (\% of GDP). Emerging market countries are Argentina, Brazil, Chile, India, Indonesia, Korea, Malaysia, Mexico, Peru, Philippines, South Africa, Thailand, Turkey and Venezuela. Developed market countries are Australia, Austria, Belgium, Denmark, Finland, France, Germany, Greece, Hong Kong, Ireland, Italy, Japan, Netherlands, New Zealand, Norway, Portugal, Singapore, Spain, Sweden, Switzerland, UK, and the United States.

\begin{tabular}{|c|c|c|c|c|}
\hline & \multicolumn{2}{|c|}{ Emerging market countries } & \multicolumn{2}{|c|}{ Developed market countries } \\
\hline & Mean & Median & Mean & Median \\
\hline \multicolumn{5}{|l|}{ Foreign trade } \\
\hline Exports & 38.0 & 30.4 & 51.9 & 38.5 \\
\hline Imports & 34.0 & 29.5 & 47.9 & 32.9 \\
\hline \multicolumn{5}{|l|}{ Financial market development } \\
\hline Market capitalization & 54.6 & 40.6 & 101.7 & 83.9 \\
\hline Private credit & 52.7 & 35.0 & 117.6 & 106.9 \\
\hline \multicolumn{5}{|l|}{ Derivatives markets } \\
\hline Foreign exchange & 0.80 & 0.53 & 3.45 & 2.39 \\
\hline Interest rate & 0.23 & 0.06 & 4.33 & 2.30 \\
\hline
\end{tabular}




\section{Table 8: Conditional Exchange Rate Return Premia for Subsamples}

The table shows results of cross-sectional regressions of market betas and exchange rate exposure on stock returns in the following month (Fama-MacBeth, 1973). Market betas and exchange rate exposure are estimated in rolling window time-series regressions of the value-weighted market index and the exchange rate index on the stock returns of nonfinancial firms. The table shows the mean coefficients (return premium) for each factor and corresponding $p$-values as well as the number of observations (N). Standard errors are corrected with the Newey-West (1987) procedure. Results are shown for regressions that use all periods as well as results broken down in two groups based upon whether the local currency appreciated or depreciated during the return premium determination month. Panels A and B show results for firms in the 14 emerging market countries, excluding return observations as well as exposures estimated using any observations for the following countries and years: Argentina (1999-2002), Brazil (1998-1999), Chile (1998-1999), Indonesia (1997-1999), Korea (1997-1999), Malaysia (1997-1999), Mexico (1994), Peru (1994), Philippines (1997-1999), Thailand (1997-1999), Turkey (2001), Venezuela (1994-1996). Panel B shows results for firms in these emerging market countries excluding return observations as well as exposures estimated using any observations for the following countries and years: Argentina (1994-2006), Brazil (1994-1998), Chile (1994-1999), Indonesia (1994-1997), Korea (1994-1997), Malaysia (1994-2006), Thailand (1994-1998), Venezuela (1994-2006). Panel C shows results for firms in developed market countries outside the Euro area, i.e. Canada, Japan, UK, and the United States. Panel D shows results for firms in developed market countries excluding the United States.

\begin{tabular}{|c|c|c|c|c|c|c|}
\hline & \multicolumn{2}{|c|}{ All periods } & \multicolumn{2}{|c|}{$\begin{array}{c}\text { Local currency } \\
\text { depreciation }\end{array}$} & \multicolumn{2}{|c|}{$\begin{array}{c}\text { Local currency } \\
\text { appreciation }\end{array}$} \\
\hline & Coef. & $p$-value & Coef. & $p$-value & Coef. & $p$-value \\
\hline \multicolumn{7}{|c|}{ Panel A: Emerging market firms in non-crisis periods } \\
\hline Exchange rate exposure & 0.008 & 0.881 & 0.289 & 0.001 & -0.234 & 0.027 \\
\hline Market beta & -0.045 & 0.520 & -0.066 & 0.406 & -0.093 & 0.231 \\
\hline Intercept & 0.012 & 0.747 & 0.033 & 0.517 & 0.014 & 0.738 \\
\hline $\mathrm{N}$ & \multicolumn{2}{|c|}{90} & \multicolumn{2}{|c|}{81} & \multicolumn{2}{|c|}{79} \\
\hline \multicolumn{7}{|c|}{ Panel B: Emerging market firms in non-peg periods } \\
\hline Exchange rate exposure & 0.051 & 0.358 & 0.276 & 0.003 & -0.225 & 0.008 \\
\hline Market beta & -0.112 & 0.080 & -0.197 & 0.010 & 0.000 & 0.998 \\
\hline Intercept & 0.026 & 0.371 & 0.041 & 0.296 & 0.005 & 0.880 \\
\hline $\mathrm{N}$ & \multicolumn{2}{|c|}{90} & \multicolumn{2}{|c|}{82} & \multicolumn{2}{|c|}{80} \\
\hline \multicolumn{7}{|c|}{ Panel C: Developed market firms in non-Euro area countries } \\
\hline Exchange rate exposure & 0.022 & 0.594 & 0.143 & 0.005 & -0.095 & 0.109 \\
\hline Market beta & -0.107 & 0.181 & -0.119 & 0.154 & -0.044 & 0.633 \\
\hline Intercept & 0.031 & 0.220 & 0.056 & 0.021 & -0.002 & 0.945 \\
\hline $\mathrm{N}$ & \multicolumn{2}{|c|}{90} & \multicolumn{2}{|c|}{90} & \multicolumn{2}{|c|}{90} \\
\hline \multicolumn{7}{|c|}{ Panel D: Developed market firms excluding the United States } \\
\hline Exchange rate exposure & 0.009 & 0.826 & 0.128 & 0.006 & -0.079 & 0.172 \\
\hline Market beta & -0.124 & 0.084 & -0.164 & 0.025 & -0.105 & 0.209 \\
\hline Intercept & 0.037 & 0.129 & 0.066 & 0.005 & 0.018 & 0.524 \\
\hline $\mathrm{N}$ & \multicolumn{2}{|c|}{90} & \multicolumn{2}{|c|}{90} & \multicolumn{2}{|c|}{90} \\
\hline
\end{tabular}




\section{Table 9: Conditional Exchange Rate Return Premia for Real Returns}

Panel A shows results of cross-sectional regressions of market betas and exchange rate exposure on stock returns in the following month (Fama-MacBeth, 1973) for emerging market and developed market firms. Market betas and exchange rate exposure are estimated in rolling window time-series regressions of the value-weighted market index and the exchange rate index on the stock returns of non-financial firms. The table shows the mean coefficients (return premium) for each factor and corresponding $p$-values as well as the number of observations $(\mathrm{N})$. Standard errors are corrected with the Newey-West (1987) procedure. The table shows the unconditional mean coefficient on the factor loadings as well as the mean coefficients conditional on whether the local currency appreciated or depreciated during the return premium determination month. Panel B shows the mean coefficients when the return premium for the exchange rate exposure is modeled as a constant plus the contemporaneous return on the exchange rate factor and the return premium for the market beta is modeled as a constant plus the contemporaneous return on the market portfolio in that country as specified in Eq(3). The emerging market countries are: Argentina, Brazil, Chile, India, Indonesia, Korea, Malaysia, Mexico, Peru, Philippines, South Africa, Thailand, Turkey and Venezuela. The developed market countries are: Australia, Austria, Belgium, Denmark, Finland, France, Germany, Greece, Hong Kong, Ireland, Italy, Japan, Netherlands, New Zealand, Norway, Portugal, Singapore, Spain, Sweden, Switzerland, UK, and the United States. Stock returns, market returns and exchange rates are adjusted for local currency inflation.

\section{Panel A: Local Currency Appreciation and Depreciation}

\begin{tabular}{|c|c|c|c|c|c|c|}
\hline & \multicolumn{2}{|c|}{ All periods } & \multicolumn{2}{|c|}{$\begin{array}{c}\text { Local currency } \\
\text { depreciation }\end{array}$} & \multicolumn{2}{|c|}{$\begin{array}{l}\text { Local currency } \\
\text { appreciation }\end{array}$} \\
\hline & Coef. & $p$-value & Coef. & $p$-value & Coef. & $p$-value \\
\hline \multicolumn{7}{|l|}{ Emerging market firms (14 countries) } \\
\hline Exchange rate exposure & 0.040 & 0.265 & 0.176 & 0.001 & -0.119 & 0.021 \\
\hline Market beta & -0.084 & 0.106 & -0.186 & 0.008 & -0.044 & 0.521 \\
\hline Intercept & 0.037 & 0.184 & 0.045 & 0.179 & 0.037 & 0.201 \\
\hline $\mathrm{N}$ & \multicolumn{2}{|c|}{90} & \multicolumn{2}{|c|}{89} & \multicolumn{2}{|c|}{89} \\
\hline \multicolumn{7}{|c|}{ Developed market firms (23 countries) } \\
\hline Exchange rate exposure & 0.033 & 0.398 & 0.156 & $<0.001$ & -0.040 & 0.458 \\
\hline Market beta & -0.117 & 0.138 & -0.135 & 0.075 & -0.087 & 0.351 \\
\hline Intercept & 0.033 & 0.164 & 0.057 & 0.013 & 0.021 & 0.455 \\
\hline $\mathrm{N}$ & \multicolumn{2}{|c|}{90} & \multicolumn{2}{|c|}{90} & \multicolumn{2}{|c|}{90} \\
\hline
\end{tabular}

Panel B: Interacted Contemporaneous Exchange Rate and Market Return

\begin{tabular}{|c|c|c|}
\hline & Coef. & $p$-value \\
\hline \multicolumn{3}{|l|}{ Emerging market firms (14 countries) } \\
\hline Exchange rate exposure ${ }^{*}$ Exchange rate return & 0.152 & 0.001 \\
\hline Exchange rate exposure & -0.021 & 0.505 \\
\hline Market beta $*$ Market return & 0.821 & $<0.001$ \\
\hline Market beta & -0.072 & 0.071 \\
\hline Intercept & 0.042 & 0.099 \\
\hline $\mathrm{N}$ & \multicolumn{2}{|c|}{90} \\
\hline \multicolumn{3}{|l|}{ Developed market firms (23 countries) } \\
\hline Exchange rate exposure $*$ Exchange rate return & 0.124 & 0.003 \\
\hline Exchange rate exposure & 0.056 & 0.160 \\
\hline Market beta $*$ Market return & 0.811 & $<0.001$ \\
\hline Market beta & -0.098 & 0.010 \\
\hline Intercept & 0.034 & 0.138 \\
\hline $\mathrm{N}$ & \multicolumn{2}{|c|}{90} \\
\hline
\end{tabular}

